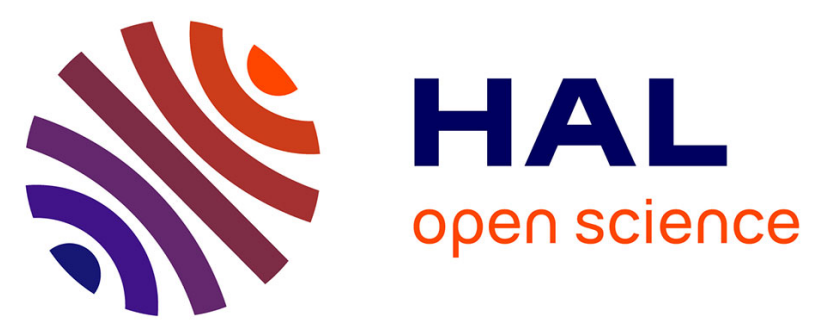

\title{
Spatiotemporal changes in the genetic diversity of harmful algal blooms caused by the toxic dinoflagellate Alexandrium minutum
}

Aliou Dia, Laure Guillou, Stéphane Mauger, Estelle Bigeard, Dominique Marie, Myriam Valero, Christophe Destombe

\section{To cite this version:}

Aliou Dia, Laure Guillou, Stéphane Mauger, Estelle Bigeard, Dominique Marie, et al.. Spatiotemporal changes in the genetic diversity of harmful algal blooms caused by the toxic dinoflagellate Alexandrium minutum. Molecular Ecology, 2014, 23 (3), pp.549-560. 10.1111/mec.12617 . hal-01132961

\section{HAL Id: hal-01132961 https://hal.science/hal-01132961}

Submitted on 23 Mar 2015

HAL is a multi-disciplinary open access archive for the deposit and dissemination of scientific research documents, whether they are published or not. The documents may come from teaching and research institutions in France or abroad, or from public or private research centers.
L'archive ouverte pluridisciplinaire HAL, est destinée au dépôt et à la diffusion de documents scientifiques de niveau recherche, publiés ou non, émanant des établissements d'enseignement et de recherche français ou étrangers, des laboratoires publics ou privés. 
SPATIOTEMPORAL CHANGES IN THE GENETIC DIVERSITY OF HARMFUL ALGAL BLOOMS CAUSED BY THE TOXIC DINOFLAGELLATE ALEXANDRIUM MINUTUM
A. Dia ${ }^{*}$, L. Guillou, S. Mauger, E. Bigeard, D. Marie, M. Valero, C. Destombe*

UPMC Paris VI, UMR 7144, Adaptation et diversité en milieu marin, Station Biologique de Roscoff, Place Georges Teissier, CS 90074, 29688 Roscoff, France.

CNRS, UMR 7144, Adaptation et diversité en milieu marin, Station Biologique de Roscoff, Place Georges Teissier, CS 90074, 29688 Roscoff, France.

Keywords: population genetics, bloom dynamics, resting cyst, linkage disequilibrium, sexual reproduction, clonality.

"Corresponding authors: Aliou Dia, Christophe Destombe

Address: Station Biologique de Roscoff, Place Georges Teissier, CS 90074, 29688 Roscoff, France.

Emails: adia@sb-roscoff.fr, destombe@sb-roscoff.fr

Running title: A. minutum spatiotemporal genetic diversity

Word count: 6968

Table count: 4

Figure count: 2

Supporting information: Dia_et al_suppinfo.doc; contains datasets. 


\begin{abstract}
Organisms with sexual and asexual reproductive systems benefit from both types of reproduction. Sexual recombination generates new combinations of alleles whereas clonality favors the spread of the fittest genotype through the entire population. Therefore, the rate of sexual versus clonal reproduction has a major influence on the demography and genetic structure of natural populations. We addressed the effect of reproductive system on populations of the dinoflagellate A. minutum. More specifically, we monitored the spatiotemporal genetic diversity during and between bloom events in two estuaries separated by $150 \mathrm{~km}$ for two consecutive years. An analysis of population genetic patterns using microsatellite markers revealed surprisingly high genotypic and genetic diversity. Moreover, there was significant spatial and temporal genetic differentiation during and between bloom events. Our results demonstrate that (1) interannual genetic differentiation can be very high, (2) estuaries are partially isolated during bloom events, and (3) genetic diversity can change rapidly during a bloom event. This rapid genetic change may reflect selective effects that are nevertheless not strong enough to reduce allelic diversity. Thus, sexual reproduction and/or migration may regularly erase any genetic structure produced within estuaries during a bloom event.
\end{abstract}




\section{Introduction}

The demography and genetics of natural populations can vary according to the rate of sexual versus clonal reproduction. These two modes of reproduction occur simultaneously in many eukaryotes. These species can benefit both from the advantage of sexual reproduction, which lies in the genetic recombination that it generates, and from the theoretical short-term demographic advantage of clonal reproduction (Maynard-Smith 1978). The relative contribution of sexual and asexual reproduction can vary within a species depending on environmental conditions (Eckert 2001; Silvertown 2008). For example in aphids, sexual reproduction is associated with the production of resting eggs that can survive harsh conditions, whereas populations living in milder environments may reproduce asexually throughout the whole year (Rispe et al. 1998). Sexual reproduction thus seems required to produce a resistant form, regardless of the genetic variability generated. In the freshwater microcrustacean Daphnia pulicaria that practices facultative sexual reproduction (alternation between parthenogenesis and sexual reproduction) during the growing season, selection on clonal lines results in an increase in genotypic adaptation and an erosion in clonal diversity (Deng \& Lynch 1996). The over-representation of certain clonal genotypes at the end of the growing season leads to greater genetic structuring and linkage disequilibrium. Similarly, most plankton species alternate between an active growing phase, during which the number of cells increases rapidly, and another phase, generally involving sexual reproduction, during which cells are in a dormant state. During the asexual reproduction phase, fitness differences among clonal lineages may cause rapid changes in genotype frequencies. In the cyclically parthenogenetic rotifer species Brachionus plicatilis, there is evidence that clonal selection occurs during the parthenogenetic phase (Gómez \& Carvalho 2000). However, sexual reproduction as well as dormant stages may slow down the response to directional selection 
and may act to maintain genetic variation when selection fluctuates (Hairston et al. 1996). Thus, in the freshwater copepod Diaptomus sanguineus, the dormant cells may act as a reservoir of genotypes (similar to a seed bank) produced in past environments, but they also may interact as a part of the selection-response dynamics in the current environment (Hairston et al. 1996).

An extreme case of alternation of an asexual growing phase and a dormant sexual phase is exemplified by unicellular phytoplankton bloom species involved in harmful algal blooms (HABs). Compared to multicellular organisms, these unicellular organisms are characterized by a ubiquitous distribution, suggesting very large population sizes and broad dispersal abilities (Cloern 1991; Finlay \& Fenchel 2004; Norris 2000). Nevertheless, dispersal of marine phytoplankton is a hotly debated issue and published results are subject to controversies. Studies on marine phytoplankton dispersal differ vastly with respect to study scale, sampling strategy (e.g. sampling few individuals per global geographic region; population samples) and the resolution of the characters or markers used (e.g. morphological markers; highly variable, microsatellite-type molecular markers). For example, using morphological criteria, Cermeno and Falkowski (2009) argue that the biogeographical distribution of fossil diatom genera is ubiquitous and that these taxa thus have no geographic structure. However, more recent studies using microsatellite markers demonstrate that there is genetic differentiation within a single species, the toxic diatom Pseudo-nitzschia pungens, on a very large scale (i.e. samples from the Atlantic and Pacific Oceans) (Casteleyn et al. 2010). The issue of connectivity between populations remains unresolved because there is little information on the distance that a single phytoplankton cell can cover and because there are only a few studies on how the marine physical environment influences dispersal. Exploring these factors is necessary for a better understanding of the ecology and evolution of plankton 
organisms (Palumbi 1994). Over the past several years, more and more studies have focused on spatiotemporal differentiation in dinoflagellate populations. For example, in the Gulf of Maine, genetic differentiation was found between two subpopulations investigated during offshore blooms, corresponding to the beginning and the end of a bloom event (which lasts about 2 months), but in different geographic locations (northern and southern, separated by hundreds of km) (Erdner et al. 2011). Other work (Richlen et al. 2012) shows spatiotemporal differentiation in the estuaries of Massachusetts (Nauset Marsh system and the Gulf of Maine) at two sites, but only one site was sampled throughout the whole bloom event (from beginning to end), precluding any comparison between dates of the same bloom at different sites. Whatever their scale, these previous studies demonstrate genetic differentiation between sites and high genetic diversity within a given bloom event. This differentiation of bloom populations and their high genetic diversity leads to questions on the role of the two life-cycle phases on population dynamics and the importance of sexual reproduction relative to clonal reproduction.

The dinoflagellate Alexandrium minutum (Halim 1960) is one of the main species involved in paralytic shellfish poisoning (PSP) blooms off the coasts of France. This microalga produces saxitoxins that can accumulate along the trophic food web. They produce PSP events that cause cases of human poisoning, typically by ingestion of contaminated shellfish. This species shows an alternation of asexual and sexual phases. The vegetative cell is haploid and sexual reproduction takes place when the environmental conditions become unfavorable (Figueroa et al. 2011). Sexual reproduction is the result of the fusion between two gametes, forming a planozygote (Probert et al. 2002). This stage changes into a resting cyst that sinks to the sediment (like seeds in a seed bank) (Wyatt \& Jenkinson 1997). After a dormancy period of several months (Garcés et al. 2004; Figueroa et al. 2007), cysts may 
germinate and give rise to vegetative haploid cells that reproduce asexually in the water column.

The objective of this study was to study the effect of asexual and sexual reproduction on the population genetic structure of this toxic dinoflagellate $A$. minutum on a small scale, both in space and in time. We used microsatellite markers to analyze monoclonal cultures of $A$. minutum isolated from samples taken at two sites located along the French coast of the English Channel, separated by roughly $150 \mathrm{~km}$, for two consecutive annual bloom events and at three different periods during each bloom event. We specifically addressed the following questions: (1) To what degree are different estuaries within the same geographic region connected? (2) What role does sexual reproduction play in the dynamics of the bloom populations? (3) Finally, is there any temporal genetic structuring during bloom events?

\section{Materials and Methods}

\section{Sampling sites and strain collection}

More than 1240 strains of dinoflagellates (different species) were collected in the Penzé estuary $\left(48^{\circ} 37^{\prime} 37.57^{\prime \prime} \mathrm{N}, 3^{\circ} 57^{\prime} 13.17^{\prime \prime} \mathrm{W}\right)$ and the Rance estuary $\left(48^{\circ} 31^{\prime} 49.61^{\prime \prime} \mathrm{N}\right.$, 1 ${ }^{\circ} 58$ '21.81'W, Table 1). These two estuaries are separated by approximately $150 \mathrm{~km}$ (Fig. 1). A. minutum blooms occurred concomitantly in both ecosystems in early summer. In 2010, blooms extend from 17 May to 12 July in the Rance estuary (maximum density of $4.2 \times 10^{4}$ cells/ $\mathrm{L}^{-1}$ observed on June 22) and from 2 June to 7 July in the Penzé estuary (maximum density of $3.710^{5}$ cells $/ \mathrm{L}^{-1}$ observed on 8 June). In 2011, blooms lasted from 11 May to 20 June in Rance (maximum density of $4.310^{5}$ cells $/ \mathrm{L}^{-1}$ observed on 27 May) and from 1 June to 8 July in Penzé (maximum density of 2.6 cells $/ \mathrm{L}^{-1} 10^{5}$ observed on 23 June). 
Plankton samples were collected from these two sites during the developmental phase of the bloom (beginning), during the maintenance phase (middle) and during the decline phase (end of the bloom event) whenever possible in each of two study years (2010 and 2011). All strains were obtained by micropipetting one single cell into fresh medium; 530 of these strains survived and 265 strains of A. minutum were genotyped. They were maintained at $19^{\circ} \mathrm{C}$ with $70 \mu \mathrm{E} . \mathrm{m}^{2} . \mathrm{s}^{-1}$ of light in a $12: 12$ light:dark cycle. The medium F/2 (Marine Water Enrichment Solution, Sigma) was prepared using autoclaved natural seawater from the Penzé estuary. It was collected at least 3 months prior to use and stored in the dark. Strains used in this study (see supplementary Table S1) have been deposited at the Roscoff Culture Collection (www.sb-roscoff.fr/Phyto/RCC).

\section{Flow cytometry}

The DNA content of each monoclonal strain was checked by flow cytometry on whole A. minutum cells fixed in ethanol. A $250 \mu \mathrm{L}$ aliquot of each culture was centrifuged at 3000 rpm for $10 \mathrm{~min}$. The supernatant was removed, cells were then re-suspended by vortexing in $250 \mu \mathrm{L}$ of $70 \%$ ethanol and kept overnight at $4{ }^{\circ} \mathrm{C}$. Cells were collected by centrifugation at $3000 \mathrm{rpm}$ for $10 \mathrm{~min}$ to remove ethanol and then resuspended in $250 \mu \mathrm{L}$ of PBS. Triton X100 (0.1\% final), RNase A $(0.01 \%)$ and Propidium Iodide (PI, $\left.30 \mu \mathrm{g} \cdot \mathrm{mL}^{-1}\right)$ were added. Samples were incubated at $37^{\circ} \mathrm{C}$ for $30 \mathrm{~min}$ before flow cytometry analysis, performed using a FACS Canto II (Becton Dickinson, San Jose, CA, USA) flow cytometer equipped with a $488 \mathrm{~nm}$ laser and the standard filter setup. The DNA content of A. minutum strains was evaluated by comparison with Human Blood Cells (HBCs, 2C =6.4 Mbp). Isolated nuclei of human blood cells were obtained by resuspending $10 \mu \mathrm{L}$ of blood in $1 \mathrm{~mL}$ of NIB buffer (Marie et al. 2000). Then, $10 \mu \mathrm{L}$ of this suspension was added to $250 \mu \mathrm{L}$ of A. minutum culture re-suspended in PBS buffer before staining. Then, all cultures were analyzed by flow 
cytometry without HBC and mean florescence of PI were compared to check for ploidy level differences.

DNA extraction, strain identification and genotyping

For DNA extraction, strains were collected during their exponential growth stage (strains listed Table 1). DNA was extracted using either the CTAB method (Lebret et al. 2012) or the Nucleospin 96 Plant kit (Macherey-Nagel, Düren, Germany), according to the manufacturer's instructions, using 5-10 mg of dried tissue resuspended in $100 \mu \mathrm{L}$ elution buffer.

Strains were screened using the intergenic region of ribosomal DNA (ITS1, 5.8S and ITS2). PCR mixes (14 $\mu \mathrm{L}$ in total) included $20 \mathrm{ng}$ of DNA, 1X GoTaq Flexi green buffer (Promega, Madison, WI, USA), $150 \mu \mathrm{M}$ of each dNTP (Thermo Fisher Scientific Inc., Waltham, MA, USA), 20 pmol of the forward primer 329F (5'-GTG AAC CTG CRG AAG GAT CA-3', complementary reverse of the eukaryote reverse primer 329-R (Moon-van der Staay et al. 2001), 20 pmol of the reverse primer DIR-R (5'- TAT GCT TAA AAT TCA GCA GGT-3' (Scholin \& Anderson 1994), and 1.25 U GoTaq ${ }^{\circledR}$ Polymerase (Promega). Amplification was carried out in a DNA Engine Peltier Thermal Cycler (Bio-Rad, Hercules, CA, USA) with the following cycling conditions: an initial denaturation at $95^{\circ} \mathrm{C}$ for $5 \mathrm{~min}$, followed by $35 \mathrm{PCR}$ cycles (denaturation at $95^{\circ} \mathrm{C}$ for $45 \mathrm{~s}$, annealing at $53^{\circ} \mathrm{C}$ for $45 \mathrm{~s}$, and extension at $72^{\circ} \mathrm{C}$ for $45 \mathrm{~s}$ ), followed by a final extension at $72^{\circ} \mathrm{C}$ for $10 \mathrm{~min}$. The PCR products were purified using the BigDye ${ }^{\circledR}$ Terminator v3.1 Cycle Sequencing kit (Applied Biosystems, Foster City, CA, USA) for subsequent bidirectional sequencing using a capillary sequencer type ABI 3130XL (Applied Biosystems).

The strains were genotyped using the 12 microsatellite markers developed by (Nagai et al. 2006). Amplification of microsatellite loci was carried out in a $10 \mu \mathrm{L}$ final volume with the 
following components: 20 ng DNA, 1x GoTaq ${ }^{\circledR}$ Flexi buffer (Promega), $2 \mathrm{mM} \mathrm{MgCl}_{2}, 150$ $\mu \mathrm{M}$ each dNTP (Thermo Fisher Scientific Inc.), $0.8 \mu \mathrm{g} . \mu \mathrm{L}^{-1}$ bovine serum albumin, $30 \mathrm{pmol}$ fluorescent-labeled forward primer (FAM, VIC, NED or PET), 30 pmol reverse primer, and 0.35 U GoTaq ${ }^{\circledR}$ Polymerase (Promega). PCR amplifications were carried out in a Bio-Rad DNA Engine Peltier Thermal Cycler using the following cycling conditions: an initial denaturation at $95^{\circ} \mathrm{C}$ for $5 \mathrm{~min}$, followed by $10 \mathrm{PCR}$ cycles (denaturation at $95^{\circ} \mathrm{C}$ for $30 \mathrm{~s}$, annealing at $60^{\circ} \mathrm{C}$ for $30 \mathrm{~s}$ and extension at $72^{\circ} \mathrm{C}$ for $30 \mathrm{~s}$ ) followed by 28 cycles (denaturation at $95^{\circ} \mathrm{C}$ for $30 \mathrm{~s}$, annealing at $55^{\circ} \mathrm{C}$ for $30 \mathrm{~s}$ and extension at $72^{\circ} \mathrm{C}$ for $30 \mathrm{~s}$ ), followed by a final extension at $72^{\circ} \mathrm{C}$ for $10 \mathrm{~min}$. Then, $2 \mu \mathrm{L}$ of PCR products, diluted 1:10, was added to $10 \mu \mathrm{L}$ of loading buffer containing $0.5 \mu \mathrm{L}$ of SM594 size standard (Mauger et al. 2012) and 9.5 $\mu \mathrm{L}$ of Hi-Di formamide (Applied Biosystems). The loading mix was denatured at $95^{\circ} \mathrm{C}$ for $3 \mathrm{~min}$ and run in an ABI 3130 XL capillary sequencer (Applied Biosystems) equipped with $50 \mathrm{~cm}$ capillaries. Genotypes were scored manually using GeneMapper version 4.0 (Applied Biosystems).

\section{Genetic analyses}

To increase sample size, close sampling dates were pooled (i.e. PZ10D, PZ11B and RC11D, Table 1) and ultimately only 11 samples with a minimum sample size of 15 strains were used in the genetic analysis (i.e. RC10D was excluded from the analyses; see Table 1).

\section{Genetic diversity and multilocus genotype diversity}

Because strains of A. minutum are haploid, the frequencies of null alleles were estimated by direct observation. After two re-amplifications, strains for which more than half of the loci did not amplify correctly were removed from the dataset. The absence of amplification at loci in other strains was considered as a null allele. Standard measures of genetic diversity (mean 
number of alleles per locus (Na), Nei's unbiased estimator of genetic diversity $\left(H_{s}\right.$; Nei 1987), and allelic richness (Ra)) for each sampling date and site were calculated using Fstat (version 2.9.3.2; Goudet 2001). Allelic richness was estimated after randomly subsampling each sample (10,000 randomizations) to standardize the minimum sample size among populations. Test for differences among groups, Fstat (Goudet 2001) was used to test the difference between the $H_{s}$ values obtained at the beginning phases (PZ11A, RC10A, RC11A) and at the end phases of bloom events (PZ10D, PZ11D, RC11D). Genclone (Arnaud-Haond et al. 2005) was used to test the efficiency of the microsatellite marker set to discriminate the maximum clonal diversity available in the data set and to calculate the number of distinct multilocus genotypes observed $(\mathrm{G})$.

\section{Linkage Disequilibrium}

Linkage disequilibrium (LD) was assessed using a single multilocus measurement of LD that is provided by the association index $\overline{\mathrm{r}}_{\mathrm{d}}$ (Brown et al. 1980 modified by Agapow \& Burt 2001) and was computed using MultiLocus ver 1.2. (Agapow \& Burt 2001). Significance tests were based on comparisons of the observed value to those of randomized datasets generated from 1000 permutations (Burt et al. 1996). The global $P$-value was calculated using a generalized binomial procedure to combine independent data (Teriokhin et al., 2007; De Meeûs et al., 2009).

\section{Genetic differentiation}

$F_{\text {st }}$ values were calculated between all pairs of populations using GENETIX 4.05 (Belkhir et al., 1996-2004), their significance was assessed using 1.000 permutations and D (Dest; Jost, 2008) was estimated with SMOGD 1.25 (Crawford, 2010). Different levels of comparison were thus considered: among dates during a bloom event, among dates within a 
site, and between sites. These data were summarized and statistically tested with a principal component analysis (PCA) performed using PCA-GEN software (version 1.2; Goudet 1999). The statistical significance associated with each axis was evaluated after 10,000 randomizations.

The partitioning of genetic variation at different hierarchical levels was examined using molecular analyses of variance (AMOVA) in Arlequin 3.5.1.2 (Excoffier \& Lischer 2010). There was only one sampling date during the 2010 bloom in Rance (Table 1); it was therefore only possible to conduct the two following analyses. First, variation was assessed on the 2011 samples by determining the variance component attributable to between-sites differentiation and to among in-bloom phases within a site. Second, variation was examined in more detail only at Penzé by determining the variance component attributable to between-years differentiation and to among in-bloom phases within years. The significance $(P<0.05)$ of the fixation indices was evaluated based on 10,000 permutations.

\section{Results}

\section{Isolation and identification of strains}

Of the 1240 isolated cells, we obtained 530 usable strains for this study (i.e. $43 \%$ success rate). The survival rate by sampling date ranged from $27 \%$ to $66 \%$. Of these 530 monoclonal strains, $364(66 \%)$ were assigned to A. minutum showing a unique haplotype corresponding to $100 \%$ similarity with a 550 bp of the rDNA sequence (covering ITS1, the 5.8S rRNA gene, and ITS2) (McCauley et al. 2009; Casabianca et al. 2011) were selected (Table 1). Indeed, this unique sequence corresponds to an A. minutum sequence (AM1 strain) previously published in GenBank (EU707466). The comparison of A. minutum DNA content 
shows that whole cells of $A$. minutum analyzed contain the same level of ploidy (32 Mbp, Fig. S1).

\section{Genetic diversity}

After re-amplifying strains with dubious amplification, 5 of the 12 loci (Aminu39, Aminu44, Aminu10, Aminu15 and Aminu29) developed by Nagai et al. (2006) were removed from the dataset. We also removed strains for which more than half of the loci did not amplify correctly. The final dataset included seven loci amplified on 265 individual strains (Table S2). For these loci, the frequency of null alleles varied from $8 \%$ for locus Aminu11 to $22 \%$ for locus Aminu20. The efficiency of the microsatellite loci to discriminate the maximum clonal diversity available in the sample is given Fig. S2. Of the 265 strains analyzed, 265 (100\%) had unique seven-locus genotypes; there were therefore no repeated genotypes in any of the analyzed strains.

The PCR products of these seven microsatellite markers showed one single band, i.e. one allele. All loci were polymorphic. The genetic diversity indices are given in Table 2 . The number of alleles varied among bloom populations, with some populations having twice as many alleles as other populations (cf. RC11A and RC10A, Table 2), and with sampling effort. Allele richness, corrected for sampling size, varied from 6.49 (RC11A) to 9.01 (RC11C). The per-locus and per-population numbers of alleles $\left(N_{\mathrm{a}}\right)$ ranged from 3 (locus A41) to 17 (locus A20) alleles. Whatever the sampling date during bloom events, Penzé and Rance showed high genetic diversities, with $H_{\mathrm{s}}$ values ranging from 0.79 to 0.88 . These genetic diversity values did not differ between the beginning and the end phases of a bloom event within an estuary (permutation test of comparison among groups; $P$-value $=0.647$ ).

Tests of linkage disequilibrium revealed an overall $P$-value of 0.525 . Of the 11 spatiotemporal samples, only one showed significant $\bar{r}_{d}$ (i.e. linkage disequilibrium estimator) 
values. This sample from Penzé (PZ11D) had a $P$-value of 0.047 , with $\bar{r}_{\mathrm{d}}$ values of 0.068 (Table 3).

\section{Genetic differentiation}

The results of the PCA (Fig. 2) show a significant overall $F_{\text {st }}$ value of 0.073 . The first two PCA axes were significant and explained 44\% of the variance: axis 1 accounts for $26.39 \%$ of the variance $\left(F_{\mathrm{st}}=0.019, P=0.001\right)$ and axis 2 accounts for $17.65 \%$ of the variance $\left(F_{\mathrm{st}}=0.013, P=0.011\right)$. Axis 1 separates samples from the beginning of the 2010 bloom (PZ10A-RC10A) from the rest of the samples (Fig. 2). Axis 2 separates samples according to the sampling date during a bloom and their geographic origin. Samples from the beginning of the bloom were less genetically differentiated than samples from the end of the bloom events. These last samples formed distinct clusters according to their geographic origin (Fig. 2; cf. PZ11C, PZ11D compared to RC11D and RC11C).

Genetic differentiation between pairs of samples $\left(F_{\mathrm{st}}\right)$ ranged from -0.0035 (RC11A vs. RC11B) to 0.0770 (RC10A vs. PZ11C), whereas $\mathrm{D}_{\text {est }}$ ranged from 0.0589 (RC11B vs. RC11C) to 0.4695 (RC10A vs. PZ11C) (Table 3S). The lowest $F_{\text {st }}$ values were observed for two samples from the same site in the same year at two consecutive in-bloom sampling dates, whereas the highest values were observed for samples between different sites and different years. The tests of differentiation at different spatial and temporal levels confirm the PCA results. They indicate that the early bloom samples in Penzé and Rance taken in 2010 (PZ10A and RC10A) differed significantly from all other samples (Table S3).

The first AMOVA helped gauge the importance of spatial variation with respect to phase variation within a bloom. This AMOVA could only be applied on the 2011 samples (Table 4A) and revealed that the genetic differentiation was significant between sites and among bloom phases within sites. More specifically, the percent of variation explained by the 
genetic differentiation during the different phases of the bloom event was three times higher (3.87\%) than the genetic differentiation between the Penzé and Rance sites $(1.23 \%$, Table $4 \mathrm{~A})$.

The second AMOVA was used to analyze the importance of temporal variation at two hierarchical levels: interannual and intrabloom (Table 4B). This temporal AMOVA could only be applied to the Penzé estuary. The results show again that the two levels of differentiation were significant. The percent variation explained by genetic differentiation between the different in-bloom periods was weaker (4.27\%, Table $4 \mathrm{~B})$ than that explained by genetic differentiation between 2010 and 2011 (10.01\%, Table 4B).

\section{Discussion}

\section{Clonal reproduction versus sexual reproduction}

The reproductive system can play an important role in the functioning and evolution of populations by modifying their dynamics, their diversity and their population genetic structure. As in many other phytoplankton species, the dinoflagellate species A. minutum is characterized by high rates of clonal reproduction during the development of bloom events, followed by a period of sexual reproduction that produces resting cysts, coinciding with the maximum and the decline of cell concentrations, respectively (Garcés et al. 2004, Bravo et al. 2010). During periods of asexual division, differences in selective values between clonal lines can rapidly lead to differences in genotype frequencies. Numerical simulations show that selective sweeps can occur when rapidly growing clones become more abundant within a population (Rynearson \& Armbrust 2000). During a bloom event, advantageous genotypes may increase in frequency, leading to an overall decrease in genetic diversity via genetic hitchhiking over the whole genome (Maynard-Smith et al. 1993). Even in the absence of 
selection, low clonal diversity and linkage equilibrium provide evidence that sexual reproduction occurs in a population with clonal reproduction. At the end of a bloom, the most frequent clones would thus preferentially participate in the production of the following generation via sexual reproduction. However, in rapidly growing organisms with short generation times, the huge population sizes can be considered as virtually infinite and genotypic diversity can thus be maintained during the bloom events, even if organisms primarily reproduce clonally (Bengtsson 2003).

In this study, all the analyzed clones were genetically distinct, suggesting that bloom events involve huge effective population sizes. The high genetic diversity observed here indicates that asexual reproduction does not predominate within A. minutum populations. It however does suggest that blooms were initiated by numerous different sexual cysts. Our results corroborate the recent observations reported for Alexandrium fundyense showing unique multilocus genotypic frequencies of $81 \%$ to $97 \%$ (Erdner et al. 2011; Richlen et al. 2012). Likewise, a study on Alexandrium tamarense has shown that the probability of sampling clones with the same genotype is practically nil due to the large population sizes of blooms (Nagai et al. 2007). The high genotypic diversity as well as the high gene diversity values observed in our study $\left(0.78<H_{\mathrm{s}}<0.87\right)$ are comparable to those of Mediterranean populations of the same species $\left(0.62<H_{\mathrm{s}}<0.89\right.$; Casabianca et al. 2011). There are reports of similar high genotypic diversity values in other phytoplankton species, such as the haptophyte (Prymnesium parvum) and the Raphidophyceae species (Gonyostomum semen) using AFLP genetic markers (Barreto et al. 2011; Lebret et al. 2012).

The continuous germination of resting cysts during the entire bloom event (Lebret et al. 2012), as well as the specific cohort of these cysts produced during successive annual blooms and stored in the cyst bank, may enhance genetic diversity (in terms of genotypes and genes) 
(Alpermann et al. 2009). Furthermore, we cannot exclude the possibility that sexual reproduction maintains genetic diversity, even during a bloom event. Observations in in vitro cultures suggest that the zygote (planozygote) may undergo meiosis without forming a resting cyst (Figueroa et al. 2007), thereby producing new vegetative cells. This type of reproduction may be promoted by the presence of the parasite Parvilucifera sinerae (Alveolata), and shortcircuiting the resting cyst stage may possibly constitute a strategy to avoid the parasite (Figueroa et al. 2010). Two different species belonging to genus Parvilucifera were detected during the 2010 and 2011 sampling cruises (Lepelletier et al. submitted). However, unfortunately, there have been no investigations to identify this type of reproduction.

In our study, no global multilocus linkage disequilibrium was detected, suggesting that recombination is sufficient to break down linkages between loci, confirming that $A$. minutum reproduces sexually. Only one sample taken during the late bloom period in Penzé in 2011 (PZ11D) showed significant multilocus linkage disequilibrium, as estimated using $\overline{\mathrm{r}}_{\mathrm{d}}$ ).

\section{Spatiotemporal genetic structure of bloom events}

The results of the microsatellite analysis clearly indicate that A. minutum blooms are structured both in space and in time. Our study shows that there is a temporal genetic differentiation during and between A. minutum blooms as well as spatial differentiation between sites. Thus, the overall genetic differentiation observed between the Rance and Penzé estuaries separated by roughly $150 \mathrm{~km}$ was significant. This result suggests that gene flow via tidal currents is limited in A. minutum, as demonstrated in A. tamarense (Nagai et al. 2007). Given the short duration of $A$. minutum bloom events (30 days on average) and that they are geographically restricted to estuaries, the gene flow between populations is likely limited. Genetic differences observed between the two estuaries late bloom samples confirm the genetic isolation between estuaries during the bloom period. However, early bloom samples 
showed weaker spatial differentiation (Table 4). This observation suggests that the Penzé and Rance estuaries communicate during spring tides, potentially transporting vegetative cells or cysts via the residual west-east tidal currents. During the bloom season, which preferentially occurs during neap tides, the two estuaries are likely isolated and the accumulation of bloom biomass is mainly due to a response to water flow and to constant, suitable environmental conditions (i.e. salinity temperature, irradiance and nutrient supply) (Anderson et al. 2012). In our study, interannual genetic differentiation was greater than intrabloom differentiation, suggesting that blooms are not only made up of newly formed cysts produced during the preceding year, but also of recruitment from migrant vegetative cells and/or from an older cyst bank (Estrada et al. 2010). Even if a multigenerational cyst bank gives rise to a bloom event, the germination of cysts may be influenced by environment conditions and, by chance or selection, samples become more differentiated than the more homogeneous cyst bank that produced them (McCue \& Holtsford 1998). The constant germination of the cyst bank may thus lead to a decrease in the interannual $F_{\mathrm{st}}$. Nevertheless, the cyst bank does not appear to contribute regularly to bloom events because the 2010 Penzé sample PZ10D was not genetically different from the early 2011 Penzé bloom sample (PZ11A). Therefore, the 2011 early bloom sample may have been composed at least partly of cysts produced in the preceding year.

In isolated estuaries, there were significant genetic changes during a bloom event (see AMOVA, Table 4A). Although no additional signatures of selection, such as multilocus linkage disequilibrium, could be detected with the neutral markers used in this study, we believe that, in these very large populations, genetic changes may nevertheless be driven by selection (see below). These genetic changes are concordant with those reported for $A$. fundyense blooms in Massachusetts where temporal intrabloom differentiation has also been 
observed (Richlen et al. 2012). Two factors can account for this temporal differentiation. First, changes may be due to delayed germination of different cohorts of cysts buried in the sediments and/or continuous encystment by a small percentage of motile cells (Pitcher et al. 2007). In Gonyostomum semen (Raphidophyceae), Lebret et al. (2012) suggest that continuous germination of cysts during a bloom is a key element behind rapid genetic changes. Second, these changes may be the result of local abiotic or biotic selection as suggested for the diatom Ditylum brightwellii (Rynearson \& Armbrust 2005; Rynearson et al. 2006). In these large populations, the effects of natural selection may predominate over those of genetic drift on genetic structure. Thus, in D. brightwellii, the succession of genetically distinct populations in different environmental conditions appears to reflect a tight coupling between environment and genetics (Rynearson et al. 2006). Of the various abiotic factors, seasonal temperature variation is one parameter that can explain the maintenance of genetic diversity (Maynard-Smith and Hoekstra 1980; Bell 1982). Recent studies on the diatom Asterionella formosa have demonstrated that variation in temperature may contribute to maintaining genetic diversity in blooms (Gsell et al. 2012). In this species, reaction norms of clone growth studied as a function of environmental temperature reveal considerable genetic diversity within a bloom. In our study, fluctuating temperatures may explain not only the maintenance of genetic diversity, but also genetic changes during a bloom event. However, biotic factors, such as predation and/or parasitism, may also play a role in determining population structure and dynamics (Montagnes et al. 2008). In A. minutum, eukaryotic parasites such as Parvilucifera spp. and Amoebophrya spp. can regulate blooms (Chambouvet et al. 2008; Figueroa et al. 2010; Lepelletier et al. submitted). The impact of parasitism can be tested by analyzing the fitness of different strains and their resistance to parasites according to date and sampling site. Whatever the factors involved, our study illustrates how sexual 
reproduction and/or migration are likely to erase any selective effects that arise each year during the vegetative phase of a bloom event.

\section{Acknowledgements}

We are very grateful to Yannis Michalakis, Denis Roze and Carolyn Engel for constructive comments on an earlier draft and 3 anonymous reviewers who helped improve this manuscript. We warmly thank the IFREMER laboratory in Dinard (France) and especially Claude Lebec and Claire Rollet. Thanks to the Roscoff Culture Collection (RCC), Service Mer et Observation (Marine Operations Department) at the Roscoff Biological Station and all the partners in the Paralex project for their help with sampling. Sequences and microsatellite genotypes were generated by Morgan Perennou and Gwenn Tanguy at the Roscoff Biological Station (Ouest-Génopole). This project was carried out in partial fulfillment of Aliou Dia's $\mathrm{PhD}$ degree, supported by funds from the ANR and a $\mathrm{PhD}$ fellowship from the Brittany Regional Council (ARE10087: POPALEX). This work was financially supported by the Brittany Regional Council, the CNRS program EC2CO, the French ANR projects PARALEX ("The sixth extinction" ANR-2009-PEXT-01201) and CLONIX ("Programme Blanc" ANR11-BSV7-00704), the European Project MaCuMBa (FP7-KBBE-2012-6-311975) and the EC2CO project PALMITO. 


\section{References}

Agapow P-M, Burt A (2001) Indices of multilocus linkage disequilibrium. Molecular Ecology Notes, 1, 101-102.

Alpermann TJ, Beszteri B, John U, Tillmann U, Cembella AD (2009) Implications of lifehistory transitions on the population genetic structure of the toxigenic marine dinoflagellate Alexandrium tamarense. Molecular Ecology, 18, 2122-2133.

Anderson, D M, Alpermann, T J, Cembella, A D, Collos, Y, Masseret, E, Montresor, M (2012). The globally distributed genus Alexandrium: Multifaceted roles in marine ecosystems and impacts on human health. Harmful Algae, 14, 10-35.

Arnaud-Haond S, Belkhir K (2007) GenClone 1.0: a new program to analyse genetics data on clonal organisms. Molecular Ecology Notes, 7, 15-17.

Barreto FS, Tomas CR, McCartney MA (2011) AFLP fingerprinting shows that a single Prymnesium parvum harmful algal bloom consists of multiple clones. Journal of Heredity, 102, 747-752.

Belkhir K, Borsa P, Chikhi L, Raufaste N Bonhomme F (1996-2004) GENETIX 4.05, logiciel sous Windows TM pour la génétique des populations. Laboratoire Génome, Populations, Interactions, CNRS UMR 5171, Université de Montpellier II, Montpellier, France.

Bell G (1982) The masterpiece of nature: the evolution and genetics of sexuality Springer.

Bengtsson BO (2003) Genetic variation in organisms with sexual and asexual reproduction. Journal of evolutionary biology, 16, 189-199.

Bravo I, Isabel Figueroa R, Garcès E, Fraga S, Massanet A (2010) The intricacies of dinoflagellate pellicle cysts: The example of Alexandrium minutum cysts from a bloomrecurrent area (Bay of Baiona, NW Spain). Deep Sea Research Part II: Topical Studies in Oceanography, 57, 166-174. 
Brown AH, Feldman MW, Nevo E (1980) Multilocus structure of natural populations of Hordeum spontaneum. Genetics, 96, 523-536.

Burt A, Carter DA, Koenig GL (1996) Molecular markers reveal cryptic sex in the human pathogen Coccidioides immitis. Proceedings of the National Academy of Sciences. USA, 93, $770-773$

Casabianca S, Penna A, Pecchioli E, et al. (2011) Population genetic structure and connectivity of the harmful dinoflagellate Alexandrium minutum in the Mediterranean Sea. Proceedings of the Royal Society B: Biological Sciences, 279, 129-138.

Casteleyn G, Leliaert F, Backeljau T, et al. (2010) Limits to gene flow in a cosmopolitan marine planktonic diatom. Proceedings of the National Academy of Sciences, 107, 1295212957.

Cermeno P, Falkowski PG (2009) Controls on diatom biogeography in the ocean. Science, 325, 1539-1541.

Chambouvet A, Morin P, Marie D, Guillou L (2008) Control of toxic marine dinoflagellate blooms by serial parasitic killers. Science, 322, 1254-1257.

Cloern JE (1991) Tidal stirring and phytoplankton bloom dynamics in an estuary. Journal of marine research, 49, 203-221.

Crawford NG (2010) SMOGD: software for the measurement of genetic diversity. Molecular Ecology Resources, 10, 556-557.

De Meeûs T, Guégan JF, Teriokhin AT (2009) MultiTest V.1.2, a program to binomially combine independent tests and performance comparison with other related methods on proportional data. BMC Bioinformatics 10, 443.

Deng H-W, Lynch M (1996) Change of genetic architecture in response to sex. Genetics, 143, 203-212. 
Eckert CG (2001) The loss of sex in clonal plants. Evolutionary Ecology, 15, 501-520.

Erdner DL, Richlen M, McCauley LAR, Anderson DM (2011) Diversity and dynamics of a widespread bloom of the toxic dinoflagellate Alexandrium fundyense. Plos One, 6, e22965.

Estrada, M, Solé, J, Anglès, S, Garcés, E (2010). The role of resting cysts in Alexandrium minutum population dynamics. Deep Sea Research Part II: Topical Studies in Oceanography, 57, 308-321.

Excoffier L, Lischer HEL (2010) Arlequin suite ver 3.5: a new series of programs to perform population genetics analyses under Linux and Windows. Molecular Ecology Resources, 10, 564-567.

Figueroa RI, Garcés E, Bravo I (2007) Comparative study of the life cycles of Alexandrium tamutum and Alexandrium minutum (Gonyaulacales, Dinophyceae) in culture. Journal of Phycology, 43, 1039-1053.

Figueroa RI, Garcés E, Camp J (2010) Reproductive plasticity and local adaptation in the host parasite system formed by the toxic Alexandrium minutum and the dinoflagellate parasite Parvilucifera sinerae. Harmful Algae, 10, 1-8.

Figueroa RI, Vázquez JA, Massanet A, Murado MA, Bravo I (2011) Interactive effects of salinity and temperature on planozygote and cyst formation of Alexandrium minutum (Dinophyceae) in culture. Journal of Phycology, 47, 13-24.

Finlay BJ, Fenchel Tom (2004) Cosmopolitan metapopulations of free-living microbial eukaryotes. Protist, 155, 237-244.

Garcés E, Bravo I, Vila M, Figueroa R. I, Maso M, Sampedro N (2004) Relationship between vegetative cells and cyst production during Alexandrium minutum bloom in Arenys de Mar harbour (NW Mediterranean). Journal of Plankton Research, 26, 637-645. 
Gómez A, Carvalho GR (2000) Sex, parthenogenesis and genetic structure of rotifers: microsatellite analysis of contemporary and resting egg bank populations. Molecular Ecology, 9, 203-214.

Goudet J (1999) PCA-GENE, version 1.2. http://www2.unil.ch/popgen/softwares/pcagen.htm. (Accessed 08 April 2013).

Goudet J (2001) Fstat, a program to estimate and test gene diversities and fixation indices (version 2.9.3.2). http://www2.unil.ch/popgen/softwares/fstat.htm. (Accessed 08 April 2013).

Gsell AS, de Senerpont Domis LN, Przytulska-Bartosiewicz A, et al. (2012) Genotype-bytemperature interactions may help to maintain clonal diversity in Asterionella formosa (Bacillariophyceae). Journal of Phycology, 48, 1197-1208.

Hairston J, N G, Kearns CM, Ellner SP (1996) Phenotypic variation in a zooplankton egg bank. Ecology, 77, 2382-2392.

Halim, Y (1960) Alexandrium minutum nov. g., nov. sp., a dinoflagellate causing red water. Vie et Milieu, 11, 102-105.

Jost L (2008) G(ST) and its relatives do not measure differentiation. Molecular Ecology, 17, 4015-4026.

Lebret K, Kritzberg ES, Figueroa R, Rengefors K (2012) Genetic diversity within and genetic differentiation between blooms of a microalgal species. Environmental Microbiology, 14, 2395-2404.

Lepelletier F, Karpov SA, Le Panse S, Bigeard E, Skovgaard AA, Jeanthon C, Guillou L (2013) Parvilucifera rostrata sp. nov., a novel parasite in the phylum Perkinsozoa that infects the toxic dinoflagellate Alexandrium minutum (Dinophyceae). Protist, (Submitted). 
Marie D, Simon N, Guillou L, Partensky F, Vaulot D (2000). DNA, RNA analysis of phytoplankton by flow cytometry. In: Current Protocols in Cytometry. John Wiley \& Sons, Inc.11, 12, 1-18.

Mauger S, Couceiro L, Valero M (2012) A simple and cost-effective method to synthesize an internal size standard amenable to use with a 5-dye system. Prime Journals, 2, 40-46.

Maynard-Smith J (1978) The evolution of sex. Cambridge University Press, London, U.K.

Maynard-Smith J, Hoekstra R (1980). Polymorphism in a varied environment: how robust are the models? Genetic Research, 35, 45-57.

Maynard-Smith J, Smith N. H, O'Rourke M, and Spratt B. G (1993). How clonal are bacteria? Proceedings of the National Academy of Sciences. USA, 90, 4384-4388.

McCauley LAR, Erdner DL, Nagai S, Richlen ML, Anderson DM (2009) Biogeographic analysis of the globally distributed harmful algal bloom species Alexandrium minutum (Dinophyceae) based on rRNA gene sequences and microsatellite markers. Journal of Phycology, 45, 454-463.

McCue K, Holtsford T (1998) Seed bank influences on genetic diversity in the rare annual Clarkia springvillensis (Onagraceae). American Journal of Botany, 85, 30-30.

Montagnes D, Chambouvet A, Guillou L (2008) Responsibility of microzooplankton and parasite pressure for the demise of toxic dinoflagellate blooms. Aquatic Microbial Ecology, 53, 211-225.

Moon-van der Staay SY, De Wachter R, Vaulot D (2001) Oceanic 18S rDNA sequences from picoplankton reveal unsuspected eukaryotic diversity. Nature, 409, 607-610.

Nagai S, MCcauley L, Yasuda N, et al. (2006) Development of microsatellite markers in the toxic dinoflagellate Alexandrium minutum (Dinophyceae). Molecular Ecology Notes, 6, 756-758. 
Nagai S, Lian C, Yamaguchi S, et al. (2007) Microsatellite markers reveal population genetic structure of the toxic dinoflagellate Alexandrium tamarense (Dinophyceae) in japanese coastal waters. Journal of Phycology, 43, 43-54.

Nei M (1987) Molecular evolutionary genetics. Columbia University Press, New York, USA. Norris RD (2000) Pelagic species diversity, biogeography, and evolution. Paleobiology, 26, 236-258.

Palumbi SR (1994) Reproductive isolation, genetic divergence, and speciation in the sea. Annual Review of Ecology and Systematics. 25, 547-572.

Pitcher GC, Cembella AD, Joyce LB, Larsen J, Probyn R.A, Sebastián R (2007) The dinoflagellate Alexandrium minutum in Cape Town harbour (South Africa): Bloom characteristics, phylogenetic analysis and toxin composition. Harmful Algae, 6, 823-36.

Probert I, Lewis J, Erard-Le Denn E (2002) Morphological details of the life history of Alexandrium minutum (Dinophyceae). Cryptogamie Algologie, 23, 343-55.

Richlen ML, Erdner DL, McCauley LAR, Libera K, Anderson DM (2012) Extensive genetic diversity and rapid population differentiation during blooms of Alexandrium fundyense (Dinophyceae) in an isolated salt pond on Cape Cod, MA, USA. Ecology and Evolution, 2, 2588-2599.

Rispe C, Pierre JS, Simon JC, Gouyon PH (1998) Models of sexual and asexual coexistence in aphids based on constraints. Journal of Evolutionary Biology, 11, 685-701.

Rynearson TA, Armbrust EV (2000) DNA fingerprinting reveals extensive genetic diversity in a field population of the centric diatom Ditylum brightwellii. Limnology and Oceanography, 45, 1329-1340.

Rynearson TA, Armbrust EV (2005) Maintenance of clonal diversity during a spring bloom of the centric diatom Ditylum brightwellii. Molecular Ecology, 14:1631-1640. 
Rynearson TA, Newton JA, Armbrust EV (2006) Spring bloom development, genetic variation, and population succession in the planktonic diatom Ditylum brightwellii. Limnology and Oceanography, 51, 1249-1261.

Scholin CA, Anderson DM (1994) Identification of group- and strain-specific genetic markers for globally distributed Alexandrium (Dinophyceae). I. Rflp analysis of SSU rRNA genes. Journal of Phycology, 30, 744-754.

Silvertown J (2008) The evolutionary maintenance of sexual reproduction: evidence from the ecological distribution of asexual reproduction in clonal plants. International journal of plant sciences, 169,157-168.

Teriokhin, A.T., De Meeûs, T., Guegan, J.F. 2007. On the power of some binomial modifications of the Bonferroni multiple test. Zh. Obshch. Biol. 68, 332-340.

Wyatt T, Jenkinson IR (1997) Notes on Alexandrium population dynamics. Journal of Plankton Research, 19, 551-575.

\section{Data accessibility}

Data used in this study (supplementary Table S1) have been deposited at the Roscoff Culture Collection (www.sb-roscoff.fr/Phyto/RCC).

\section{Authors' contributions}

AD conceived the study, performed isolation and culture of strains, molecular data, analysis and drafted the manuscript, SM contributed to molecular analyses; EB performed isolation and culture of strains, DM performed cytometry analyses, MV participated in the design of the study, performed some statistical analysis and revised the manuscript, LG and CD coordinated the study, helped draft and revised the manuscript. All authors contributed to sample collection, read and approved the final manuscript. 


\section{Figure legends:}

Figure 1: Maps of the study area showing sampling stations in the two estuaries: Penzé (PZ) and Rance (RC).

Figure 2: PCA of genetic differentiation between samples taken from the Penzé and Rance estuaries in 2010 and 2011.

Figure 1:

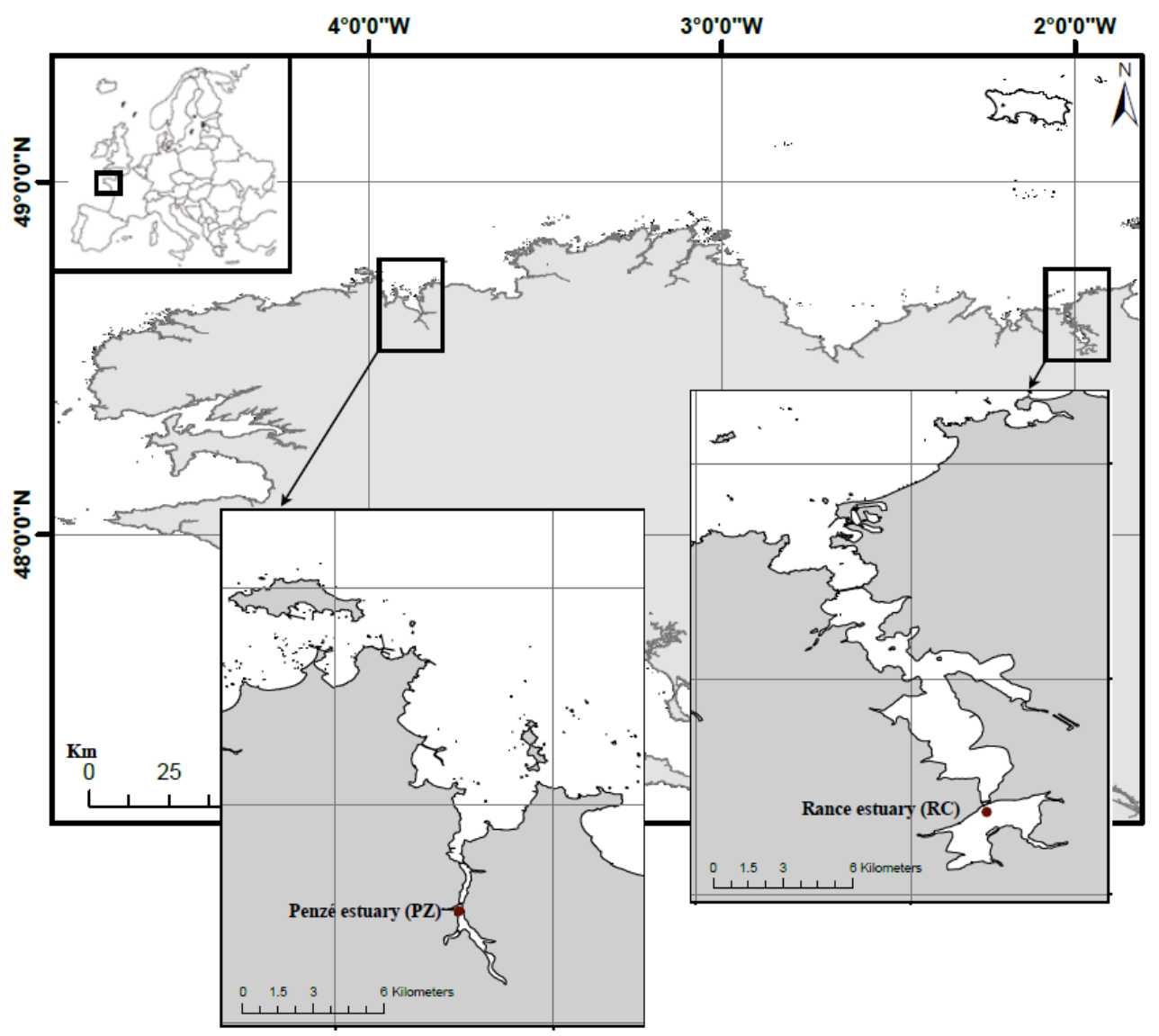


Figure 2:

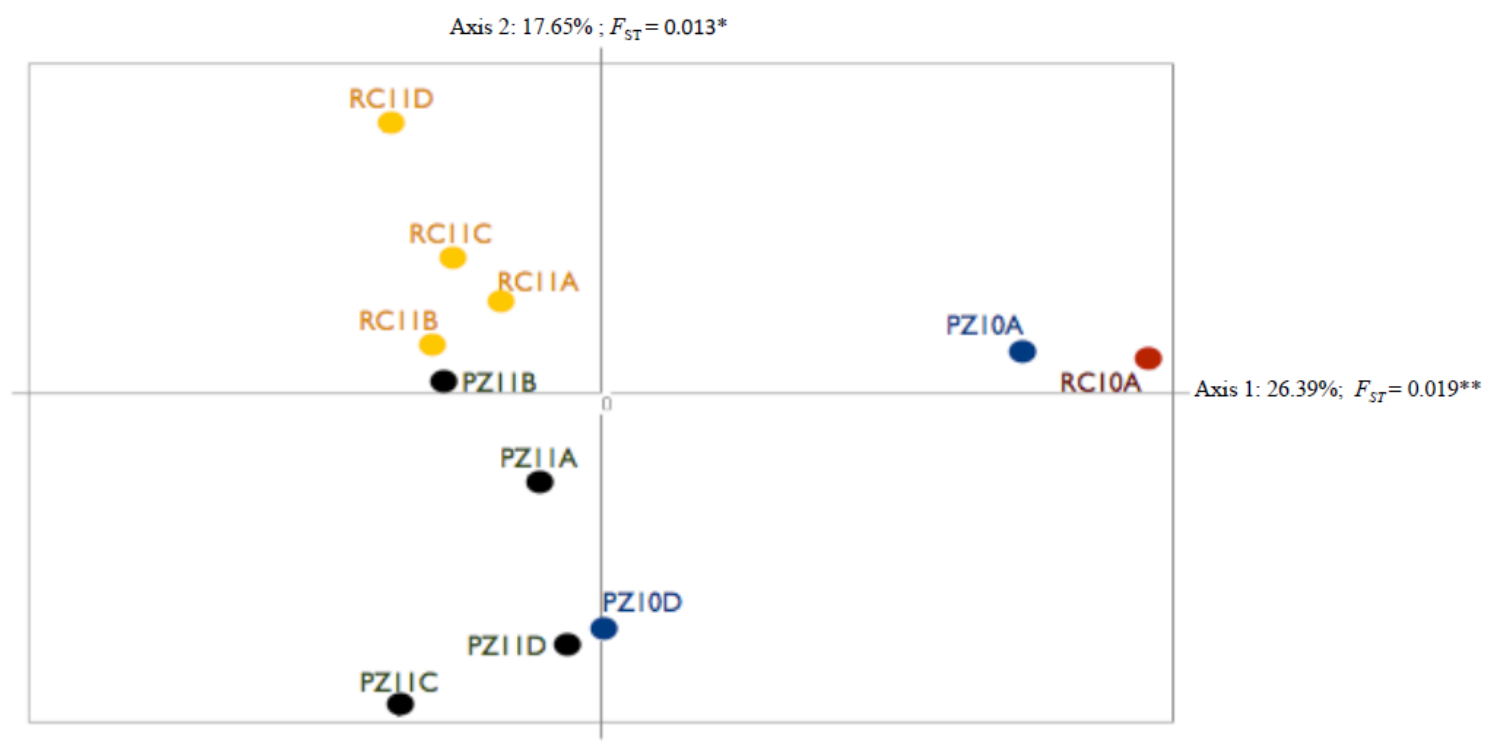



Table 1: Characteristics of the spatiotemporal sampling. Sample sizes (N) are given for strains that were isolated for culturing and for the surviving strains that were genotyped. Codes for samples: PZ for Penzé, RC for Rance; 10 for 2010 and 11 for 2011; A, B, C and D indicate respectively the different periods of the blooms: the beginning, the middle 1 , the middle 2 and the end of the bloom. Cells were counted in a counting chamber using an inverted microscope (Olympus CKX41). 


\begin{tabular}{|c|c|c|c|c|c|c|c|c|}
\hline Site/Year & $\begin{array}{c}\text { Sampling } \\
\text { date }\end{array}$ & Sample code & $\begin{array}{l}\text { Cells density } \\
\times 10^{3} \text { cells/L }\end{array}$ & $\begin{array}{l}\text { Temperature of } \\
\text { water (air } \\
\text { temperature min./ } \\
\text { max.) }\left({ }^{\circ} \mathrm{C}\right)\end{array}$ & $\begin{array}{c}\text { Number of } \\
\text { strains } \\
\text { isolated }\end{array}$ & $\begin{array}{l}\text { Number of } \\
\text { surviving } \\
\text { strains (\%) }\end{array}$ & $\begin{array}{l}\text { Number of } \\
\text { A. minutum } \\
\text { strains after } \\
\text { screening }\end{array}$ & $\begin{array}{c}\text { Number of } \\
\text { strains } \\
\text { genotyped }\end{array}$ \\
\hline \multirow[t]{3}{*}{ Penzé/2010 } & 02 June & PZ10A & 8 & $14.5(8.6 / 22)$ & 82 & $36(43.9)$ & 32 & 24 \\
\hline & 30 June & PZ10D & 102 & $19.0(13.5 / 24.5)$ & 29 & $16(55.2)$ & 09 & 09 \\
\hline & 01 July & PZ10D & 63 & $19.3(12.2 / 25.9)$ & 55 & $30(54.5)$ & 14 & 08 \\
\hline \multirow[t]{5}{*}{ Penzé/2011 } & 01 June & PZ11A & 31 & $17.9(2.7 / 18.6)$ & 85 & $55(64.7)$ & 22 & 19 \\
\hline & 15 June & PZ11B & 88 & $18.0(12.3 / 20.5)$ & 93 & $46(49.4)$ & 24 & 14 \\
\hline & 17 June & PZ11B & 171 & $15.9(8.4 / 16.3)$ & 144 & $36(25)$ & 24 & 15 \\
\hline & 22 June & PZ11C & 402 & $16.0(11.5 / 18)$ & 119 & 49 (41.2) & 32 & 24 \\
\hline & 11 July & PZ11D & ND & $17.5(9 / 23.8)$ & 195 & $30(15.4)$ & 26 & 18 \\
\hline Rance/2010 & 02 June & $\mathrm{RC} 10 \mathrm{~A}$ & 36 & $16.3(11.2 / 17.8)$ & 65 & $43(66.2)$ & 43 & 40 \\
\hline \multirow[t]{6}{*}{ Rance/2011 } & 09 May & $\mathrm{RC} 11 \mathrm{~A}$ & 13 & $15.4(9.8 / 19.7)$ & 45 & $26(57.8)$ & 19 & 15 \\
\hline & 23 May & $\mathrm{RC} 11 \mathrm{~B}$ & 168 & $16.8(7.4 / 24.2)$ & 96 & $55(55.2)$ & 40 & 25 \\
\hline & 27 May & $\mathrm{RC} 11 \mathrm{C}$ & 288 & $17.0(10.8 / 15.1)$ & 96 & $57(59.3)$ & 38 & 25 \\
\hline & 03 June & RC11D & 66 & $18.5(13 / 22.1)$ & 83 & $22(26.5)$ & 17 & 10 \\
\hline & 05 June & RC11D & 106 & $18.8(13.8 / 14.7)$ & 53 & $29(54.7)$ & 24 & 19 \\
\hline & & & & Total & 1240 & $530(42.7)$ & 364 & 265 \\
\hline
\end{tabular}


Table 2: Genetic diversity estimates in A. minutum at each of the 11 sampling sites and dates and for each of the seven microsatellite loci. $N$, number of individuals genotyped in each sample; $N_{\mathrm{a}}$, number of alleles per locus; $R_{\mathrm{a}}$, expected allelic richness based on the smallest sample size (10); $H_{\mathrm{s}}$, Nei's gene diversity.

\begin{tabular}{|c|c|c|c|c|c|c|c|c|c|c|c|}
\hline $\begin{array}{l}\text { Sample } \\
\text { (N) }\end{array}$ & $\begin{array}{l}\text { PZ10 } \\
\text { A } \\
(24) \\
\end{array}$ & $\begin{array}{l}\text { PZ10 } \\
\text { D } \\
(17) \\
\end{array}$ & $\begin{array}{l}\text { PZ11 } \\
\text { A } \\
(19) \\
\end{array}$ & $\begin{array}{l}\text { PZ11 } \\
\text { B } \\
(29) \\
\end{array}$ & $\begin{array}{l}\text { PZ11 } \\
\text { C } \\
(24) \\
\end{array}$ & $\begin{array}{l}\text { PZ11 } \\
\text { D } \\
(18) \\
\end{array}$ & $\begin{array}{l}\text { RC10 } \\
\text { A } \\
(40) \\
\end{array}$ & $\begin{array}{l}\text { RC11 } \\
\text { A } \\
\text { (15) }\end{array}$ & $\begin{array}{l}\text { RC11 } \\
\text { B } \\
(25) \\
\end{array}$ & $\begin{array}{l}\text { RC11 } \\
\text { C } \\
(25) \\
\end{array}$ & $\begin{array}{l}\text { RC11 } \\
\text { D } \\
(29) \\
\end{array}$ \\
\hline \multicolumn{12}{|c|}{ Aminu22 } \\
\hline $\mathrm{N}$ & 19 & 15 & 14 & 26 & 23 & 16 & 34 & 12 & 23 & 21 & 27 \\
\hline $\mathrm{N}_{\mathrm{a}}$ & 4 & 7 & 4 & 9 & 6 & 5 & 9 & 5 & 7 & 8 & 8 \\
\hline $\mathrm{R}_{\mathrm{a}}$ & 3.74 & 6.58 & 3.85 & 6.62 & 5.05 & 4.60 & 6.36 & 4.96 & 5.63 & 6.33 & 5.97 \\
\hline $\mathrm{H}_{\mathrm{s}}$ & 0.57 & 0.84 & 0.57 & 0.73 & 0.75 & 0.68 & 0.76 & 0.74 & 0.63 & 0.62 & 0.68 \\
\hline \multicolumn{12}{|c|}{ Aminu41 } \\
\hline $\mathrm{N}$ & 22 & 16 & 17 & 27 & 24 & 17 & 36 & 12 & 23 & 19 & 24 \\
\hline $\mathrm{N}_{\mathrm{a}}$ & 10 & 3 & 4 & 7 & 3 & 4 & 10 & 3 & 6 & 10 & 5 \\
\hline $\mathrm{R}_{\mathrm{a}}$ & 7.93 & 3.00 & 3.68 & 5.29 & 2.67 & 3.82 & 6.63 & 2.98 & 4.74 & 8.26 & 4.00 \\
\hline $\mathrm{H}_{\mathrm{s}}$ & 0.84 & 0.69 & 0.64 & 0.71 & 0.56 & 0.68 & 0.77 & 0.59 & 0.63 & 0.85 & 0.62 \\
\hline \multicolumn{12}{|c|}{ Aminu11 } \\
\hline $\mathrm{N}$ & 22 & 16 & 17 & 28 & 22 & 17 & 33 & 14 & 23 & 25 & 28 \\
\hline $\mathrm{N}_{\mathrm{a}}$ & 12 & 9 & 9 & 12 & 12 & 11 & 14 & 10 & 11 & 14 & 13 \\
\hline $\mathrm{R}_{\mathrm{a}}$ & 10.02 & 8.20 & 8.54 & 9.04 & 9.55 & 9.82 & 9.85 & 9.48 & 9.34 & 10.67 & 10.38 \\
\hline \multicolumn{12}{|c|}{ Aminu20 } \\
\hline $\mathrm{N}$ & 19 & 14 & 10 & 28 & 19 & 17 & 24 & 11 & 21 & 18 & 23 \\
\hline $\mathrm{N}_{\mathrm{a}}$ & 10 & 9 & 7 & 17 & 13 & 10 & 9 & 5 & 13 & 13 & 12 \\
\hline $\mathrm{R}_{\mathrm{a}}$ & 8.22 & 8.55 & 7.00 & 12.28 & 11.23 & 8.68 & 6.88 & 4.99 & 10.68 & 11.03 & 9.30 \\
\hline & 0.78 & 0.91 & 0.91 & 0.96 & 0.97 & 0.84 & 0.79 & 0.84 & 0.95 & 0.95 & 0.89 \\
\hline \multicolumn{12}{|c|}{ Aminu43 } \\
\hline $\mathrm{N}$ & 19 & 16 & 18 & 24 & 23 & 14 & 28 & 14 & 22 & 19 & 20 \\
\hline $\mathrm{N}_{\mathrm{a}}$ & 13 & 10 & 13 & 12 & 13 & 8 & 15 & 8 & 14 & 9 & 10 \\
\hline $\mathrm{R}_{\mathrm{a}}$ & 10.92 & 9.17 & 10.90 & 9.84 & 10.05 & 7.63 & 10.90 & 7.70 & 10.96 & 8.00 & 8.99 \\
\hline $\mathrm{H}_{\mathrm{s}}$ & 0.95 & 0.93 & 0.94 & 0.93 & 0.92 & 0.89 & 0.93 & 0.91 & 0.94 & 0.89 & 0.93 \\
\hline \multicolumn{12}{|c|}{ Aminu48 } \\
\hline $\mathrm{N}$ & 17 & 15 & 19 & 25 & 23 & 18 & 37 & 15 & 20 & 25 & 27 \\
\hline $\mathrm{N}_{\mathrm{a}}$ & 11 & 12 & 11 & 10 & 8 & 7 & 14 & 5 & 8 & 10 & 9 \\
\hline $\mathrm{Ra}$ & 9.82 & 10.96 & 9.18 & 7.71 & 6.69 & 6.36 & 8.74 & 4.78 & 6.73 & 7.74 & 6.54 \\
\hline $\mathrm{H}_{\mathrm{s}}$ & 0.94 & 0.96 & 0.87 & 0.83 & 0.83 & 0.78 & 0.85 & 0.64 & 0.80 & 0.85 & 0.68 \\
\hline \multicolumn{12}{|c|}{ Aminu08 } \\
\hline $\mathrm{N}$ & 22 & 15 & 17 & 27 & 23 & 14 & 28 & 13 & 23 & 24 & 28 \\
\hline $\mathrm{N}_{\mathrm{a}}$ & 9 & 10 & 11 & 13 & 10 & 11 & 13 & 11 & 13 & 15 & 11 \\
\hline $\mathrm{R}_{\mathrm{a}}$ & 7.38 & 9.36 & 9.82 & 9.18 & 8.22 & 10.33 & 9.67 & 10.58 & 9.90 & 11.07 & 7.91 \\
\hline $\mathrm{H}_{\mathrm{e}}$ & 0.83 & 0.94 & 0.94 & 0.87 & 0.88 & 0.96 & 0.91 & 0.97 & 0.88 & 0.93 & 0.83 \\
\hline \multicolumn{12}{|l|}{$\begin{array}{l}\text { Mean } \\
\text { over loci }\end{array}$} \\
\hline $\mathrm{N}_{\mathrm{a}}$ & 9.86 & 8.57 & 8.43 & 11.43 & 9.29 & 8.00 & 12.00 & 6.71 & 10.29 & 11.29 & 9.71 \\
\hline (SE) & 0.30 & 0.34 & 0.42 & 0.28 & 0.41 & 0.35 & 0.22 & 0.44 & 0.32 & 0.24 & 0.28 \\
\hline $\mathrm{R}_{\mathrm{a}}$ & 8.29 & 7.97 & 7.57 & 8.56 & 7.64 & 7.32 & 8.43 & 6.49 & 8.28 & 9.01 & 7.58 \\
\hline (SE) & 0.29 & 0.32 & 0.38 & 0.27 & 0.40 & 0.34 & 0.21 & 0.43 & 0.31 & 0.21 & 0.29 \\
\hline $\mathrm{H}_{\mathrm{s}}$ & 0.84 & 0.88 & 0.83 & 0.85 & 0.83 & 0.82 & 0.85 & 0.81 & 0.82 & 0.86 & 0.79 \\
\hline (SE) & 0.16 & 0.11 & 0.19 & 0.11 & 0.17 & 0.14 & 0.09 & 0.19 & 0.17 & 0.13 & 0.17 \\
\hline
\end{tabular}


Table 3: Multilocus measurements of linkage disequilibrium using $\overline{\mathrm{r}}_{\mathrm{d}}$ (Agapow and Burt 2001).

\begin{tabular}{llllllllllll}
\hline $\begin{array}{l}\text { Sample } \\
(N)\end{array}$ & $\begin{array}{l}\text { PZ10A } \\
(24)\end{array}$ & $\begin{array}{l}\text { PZ10D } \\
(17)\end{array}$ & $\begin{array}{l}\text { PZ11A } \\
(19)\end{array}$ & $\begin{array}{l}\text { PZ11B } \\
(29)\end{array}$ & $\begin{array}{l}\text { PZ11C } \\
(24)\end{array}$ & $\begin{array}{l}\text { PZ11D } \\
(18)\end{array}$ & $\begin{array}{l}\text { RC10A } \\
(40)\end{array}$ & $\begin{array}{l}\text { RC11A } \\
(15)\end{array}$ & $\begin{array}{l}\text { RC11B } \\
(25)\end{array}$ & $\begin{array}{l}\text { RC11C } \\
(25)\end{array}$ & $\begin{array}{l}\text { RC11D } \\
(29)\end{array}$ \\
\hline $\mathbf{r d}$ & -0.008 & 0.068 & -0.034 & -0.017 & 0.037 & 0.005 & 0.003 & 0.027 & -0.037 & -0.049 & 0.009 \\
& & & & & & & & & & & \\
P-value & 0.566 & 0.047 & 0.870 & 0.730 & 0.063 & 0.416 & 0.423 & 0.240 & 0.902 & 0.971 & 0.348 \\
\hline
\end{tabular}

Table 4: Spatial (A) and temporal (B) analyses of bloom events

A: Spatial AMOVA: Variation among bloom phases between the Penzé and Rance sites sampled in $2011\left(F_{\mathrm{st}}=0.05 . P<10^{-5}\right)$

\begin{tabular}{llllll}
\hline Source of variation & $\mathrm{df}$ & $\begin{array}{l}\text { Sum of } \\
\text { squares }\end{array}$ & $\begin{array}{l}\text { Variance } \\
\text { component }\end{array}$ & $\begin{array}{l}\text { Percentage } \\
\text { variation (\%) }\end{array}$ & $P$-value \\
\hline $\begin{array}{l}\text { Between the Penzé and Rance } \\
\text { sites sampled in 2011 }\end{array}$ & 1 & 13.91 & 0.04 & 1.23 & 0.008 \\
$\begin{array}{l}\text { Among bloom phases within } \\
\text { site }\end{array}$ & 6 & 44.51 & 0.12 & 3.87 & 0.002 \\
$\begin{array}{l}\text { Within bloom phase } \\
\text { Total }\end{array}$ & 318 & 896.08 & 2.82 & 94.88 & \\
\hline
\end{tabular}

B: Temporal AMOVA: Variation among bloom phases between years 2010 and 2011 at Penzé site $\left(F_{\mathrm{st}}=0.14 . \mathrm{p}<10^{-5}\right)$

\begin{tabular}{llllll}
\hline Source of variation & $\mathrm{df}$ & $\begin{array}{l}\text { Sum of } \\
\text { squares }\end{array}$ & $\begin{array}{l}\text { Variance } \\
\text { component }\end{array}$ & $\begin{array}{l}\text { Percentage } \\
\text { variation }(\%)\end{array}$ & $P$-value \\
\hline $\begin{array}{l}\text { Between years 2010 and 2011 } \\
\text { in Penzé }\end{array}$ & 1 & 41.24 & 0.33 & 10.01 & $\mathrm{p}<10^{-5}$ \\
$\begin{array}{l}\text { Among bloom phases within } \\
\text { year }\end{array}$ & 4 & 33.04 & 0.14 & 4.27 & $\mathrm{p}<10^{-5}$ \\
$\begin{array}{l}\text { Within bloom phase } \\
\text { Total }\end{array}$ & 226 & 648.12 & 2.86 & & \\
\hline
\end{tabular}



ALGAL BLOOMS CAUSED BY THE TOXIC DINOFLAGELLATE ALEXANDRIUM MINUTUM

Aliou Dia, Laure Guillou, Stéphane Mauger, Estelle Bigeard, Dominique Marie, Myriam Valero, Christophe Destombe

UPMC Paris VI, UMR 7144, Adaptation et diversité en milieu marin, Station Biologique de Roscoff, Place Georges Teissier, CS 90074, 29688 Roscoff, France.

CNRS, UMR 7144, Adaptation et diversité en milieu marin, Station Biologique de Roscoff, Place Georges Teissier, CS 90074, 29688 Roscoff, France

Figure S1. Quantification of DNA in Alexandrium minutum cultures in comparison with nuclei isolated from human blood cells (HBC, 6.4 Mbp), after staining with propidium iodide in PBS buffer. $\mathrm{HBC}$ and A. minutum are discriminated on the forward scatter (X-axis, logarithmic scale), a proxy of size, versus red fluorescence (Y-axis, linear scale) dot plot (A). Quantification of DNA (X-axis, linear scale) by fluorescence in two monoclonal strains (B) and (C).

Figure S2. Resolving power of the microsatellite marker set to discriminate the maximum clonal diversity available in the data set.

\section{Supplementary Tables (3)}

Table S1. Roscoff Culture Collection (RCC) number, origin, population code and date of isolation of strains used in this study. RCC web site: www.sb-roscoff.fr/Phyto/RCC.

\begin{tabular}{cccl}
\hline $\begin{array}{c}\text { Strain } \\
\text { number }\end{array}$ & Site & $\begin{array}{c}\text { Population } \\
\text { code }\end{array}$ & Date \\
\hline RCC 3144 & Penzé & PZ10A & 02-June-10 \\
RCC 3145 & Penzé & PZ10A & 02-June-10 \\
RCC 3146 & Penzé & PZ10A & 02-June-10 \\
RCC 3147 & Penzé & PZ10A & 02-June-10 \\
RCC 3148 & Penzé & PZ10A & 02-June-10
\end{tabular}




\begin{tabular}{|c|c|c|c|}
\hline RCC 3149 & Penzé & PZ10A & 02-June-10 \\
\hline RCC 3150 & Penzé & PZ10A & 02-June-10 \\
\hline RCC 3151 & Penzé & PZ10A & 02-June-10 \\
\hline RCC 3152 & Penzé & PZ10A & 02-June-10 \\
\hline RCC 3153 & Penzé & PZ10A & 02-June-10 \\
\hline RCC 3154 & Penzé & PZ10A & 02-June-10 \\
\hline RCC 3155 & Penzé & PZ10A & 02-June-10 \\
\hline RCC 3156 & Penzé & PZ10A & 02-June-10 \\
\hline RCC 3157 & Penzé & PZ10A & 02-June-10 \\
\hline RCC 3158 & Penzé & PZ10A & 02-June-10 \\
\hline RCC 3159 & Penzé & PZ10A & 02-June-10 \\
\hline RCC 3160 & Penzé & PZ10A & 02-June-10 \\
\hline RCC 3161 & Penzé & PZ10A & 02-June-10 \\
\hline RCC 3162 & Penzé & PZ10A & 02-June-10 \\
\hline RCC 3163 & Penzé & PZ10A & 02-June-10 \\
\hline RCC 3164 & Penzé & PZ10A & 02-June-10 \\
\hline RCC 3165 & Penzé & PZ10A & 02-June-10 \\
\hline RCC 3166 & Penzé & PZ10A & 02-June-10 \\
\hline RCC 3167 & Penzé & PZ10A & 02-June-10 \\
\hline RCC 3168 & Penzé & PZ10D & 30-June-10 \\
\hline RCC 3169 & Penzé & PZ10D & 30-June-10 \\
\hline RCC 3170 & Penzé & PZ10D & 30-June-10 \\
\hline RCC 3171 & Penzé & PZ10D & 30-June-10 \\
\hline RCC 3172 & Penzé & PZ10D & 30-June-10 \\
\hline RCC 3173 & Penzé & PZ10D & 30-June-10 \\
\hline RCC 3174 & Penzé & PZ10D & 30-June-10 \\
\hline RCC 3175 & Penzé & PZ10D & 30-June-10 \\
\hline RCC 3176 & Penzé & PZ10D & 30-June-10 \\
\hline RCC 3177 & Penzé & PZ10D & 01-July-10 \\
\hline RCC 3178 & Penzé & PZ10D & 01-July-10 \\
\hline RCC 3179 & Penzé & PZ10D & 01-July-10 \\
\hline RCC 3180 & Penzé & PZ10D & 01-July-10 \\
\hline RCC 3181 & Penzé & PZ10D & 01-July-10 \\
\hline RCC 3182 & Penzé & PZ10D & 01-July-10 \\
\hline RCC 3183 & Penzé & PZ10D & 01-July-10 \\
\hline RCC 3023 & Penzé & PZ10D & 01-July-10 \\
\hline RCC 3249 & Penzé & PZ11A & 01-June-11 \\
\hline RCC 3250 & Penzé & PZ11A & 01-June-11 \\
\hline RCC 3251 & Penzé & PZ11A & 01-June-11 \\
\hline RCC 3252 & Penzé & PZ11A & 01-June-11 \\
\hline RCC 3253 & Penzé & PZ11A & 01-June-11 \\
\hline RCC 3254 & Penzé & PZ11A & 01-June-11 \\
\hline RCC 3255 & Penzé & PZ11A & 01-June-11 \\
\hline RCC 3256 & Penzé & PZ11A & 01-June-11 \\
\hline RCC 3257 & Penzé & PZ11A & 01-June-11 \\
\hline RCC 3258 & Penzé & PZ11A & 01-June-11 \\
\hline RCC 3259 & Penzé & PZ11A & 01-June-11 \\
\hline RCC 3260 & Penzé & PZ11A & 01-June-11 \\
\hline
\end{tabular}




\begin{tabular}{|c|c|c|c|}
\hline RCC 3261 & Penzé & PZ11A & 01-June-11 \\
\hline RCC 3262 & Penzé & PZ11A & 01-June-11 \\
\hline RCC 3263 & Penzé & PZ11A & 01-June-11 \\
\hline RCC 3264 & Penzé & PZ11A & 01-June-11 \\
\hline RCC 3265 & Penzé & PZ11A & 01-June-11 \\
\hline RCC 3266 & Penzé & PZ11A & 01-June-11 \\
\hline RCC 3267 & Penzé & PZ11A & 01-June-11 \\
\hline RCC 3297 & Penzé & PZ11B & 15-June-11 \\
\hline RCC 3298 & Penzé & PZ11B & 15-June-11 \\
\hline RCC 3299 & Penzé & PZ11B & 15-June-11 \\
\hline RCC 3300 & Penzé & PZ11B & 15-June-11 \\
\hline RCC 3301 & Penzé & PZ11B & 15-June-11 \\
\hline RCC 3302 & Penzé & PZ11B & 15-June-11 \\
\hline RCC 3303 & Penzé & PZ11B & 15-June-11 \\
\hline RCC 3304 & Penzé & PZ11B & 15-June-11 \\
\hline RCC 3305 & Penzé & PZ11B & 15-June-11 \\
\hline RCC 3306 & Penzé & PZ11B & 15-June-11 \\
\hline RCC 3307 & Penzé & PZ11B & 15-June-11 \\
\hline RCC 3308 & Penzé & PZ11B & 15-June-11 \\
\hline RCC 3309 & Penzé & PZ11B & 15-June-11 \\
\hline RCC 3310 & Penzé & PZ11B & 15-June-11 \\
\hline RCC 3311 & Penzé & PZ11B & 17-June-11 \\
\hline RCC 3312 & Penzé & PZ11B & 17-June-11 \\
\hline RCC 3313 & Penzé & PZ11B & 17-June-11 \\
\hline RCC 3314 & Penzé & PZ11B & 17-June-11 \\
\hline RCC 3315 & Penzé & PZ11B & 17-June-11 \\
\hline RCC 3316 & Penzé & PZ11B & 17-June-11 \\
\hline RCC 3317 & Penzé & PZ11B & 17-June-11 \\
\hline RCC 3318 & Penzé & PZ11B & 17-June-11 \\
\hline RCC 3319 & Penzé & PZ11B & 17-June-11 \\
\hline RCC 3320 & Penzé & PZ11B & 17-June-11 \\
\hline RCC 3321 & Penzé & PZ11B & 17-June-11 \\
\hline RCC 3322 & Penzé & PZ11B & 17-June-11 \\
\hline RCC 3323 & Penzé & PZ11B & 17-June-11 \\
\hline RCC 3324 & Penzé & PZ11B & 17-June-11 \\
\hline RCC 3325 & Penzé & PZ11B & 17-June-11 \\
\hline RCC 3326 & Penzé & PZ11C & 22-June-11 \\
\hline RCC 3327 & Penzé & PZ11C & 22-June-11 \\
\hline RCC 3328 & Penzé & PZ11C & 22-June-11 \\
\hline RCC 3329 & Penzé & PZ11C & 22-June-11 \\
\hline RCC 3330 & Penzé & PZ11C & 22-June-11 \\
\hline RCC 3331 & Penzé & PZ11C & 22-June-11 \\
\hline RCC 3332 & Penzé & PZ11C & 22-June-11 \\
\hline RCC 3333 & Penzé & PZ11C & 22-June-11 \\
\hline RCC 3334 & Penzé & PZ11C & 22-June-11 \\
\hline RCC 3335 & Penzé & PZ11C & 22-June-11 \\
\hline RCC 3336 & Penzé & PZ11C & 22-June-11 \\
\hline RCC 3337 & Penzé & PZ11C & 22-June-1 \\
\hline
\end{tabular}




\begin{tabular}{|c|c|c|c|}
\hline RCC 3338 & Penzé & PZ11C & 22-June-11 \\
\hline RCC 3339 & Penzé & PZ11C & 22-June-11 \\
\hline RCC 3340 & Penzé & PZ11C & 22-June-11 \\
\hline RCC 3341 & Penzé & PZ11C & 22-June-11 \\
\hline RCC 3342 & Penzé & PZ11C & 22-June-11 \\
\hline RCC 3343 & Penzé & PZ11C & 22-June-11 \\
\hline RCC 3344 & Penzé & PZ11C & 22-June-11 \\
\hline RCC 3345 & Penzé & PZ11C & 22-June-11 \\
\hline RCC 3346 & Penzé & PZ11C & 22-June-11 \\
\hline RCC 3347 & Penzé & PZ11C & 22-June-11 \\
\hline RCC 3348 & Penzé & PZ11C & 22-June-11 \\
\hline RCC 3349 & Penzé & PZ11C & 22-June-11 \\
\hline RCC 3350 & Penzé & PZ11D & 11-July-11 \\
\hline RCC 3351 & Penzé & PZ11D & 11-July-11 \\
\hline RCC 3352 & Penzé & PZ11D & 11-July-11 \\
\hline RCC 3353 & Penzé & PZ11D & 11-July-11 \\
\hline RCC 3354 & Penzé & PZ11D & 11-July-11 \\
\hline RCC 3355 & Penzé & PZ11D & 11-July-11 \\
\hline RCC 3356 & Penzé & PZ11D & 11-July-11 \\
\hline RCC 3357 & Penzé & PZ11D & 11-July-11 \\
\hline RCC 3358 & Penzé & PZ11D & 11-July-11 \\
\hline RCC 3359 & Penzé & PZ11D & 11-July-11 \\
\hline RCC 3360 & Penzé & PZ11D & 11-July-11 \\
\hline RCC 3361 & Penzé & PZ11D & 11-July-11 \\
\hline RCC 3362 & Penzé & PZ11D & 11-July-11 \\
\hline RCC 3363 & Penzé & PZ11D & 11-July-11 \\
\hline RCC 3364 & Penzé & PZ11D & 11-July-11 \\
\hline RCC 3365 & Penzé & PZ11D & 11-July-11 \\
\hline RCC 3366 & Penzé & PZ11D & 11-July-11 \\
\hline RCC 3367 & Penzé & PZ11D & 11-July-11 \\
\hline RCC 3105 & Rance & $\mathrm{RC} 10 \mathrm{~A}$ & 02-June-10 \\
\hline RCC 3106 & Rance & RC10A & 02-June-10 \\
\hline RCC 3107 & Rance & $\mathrm{RC} 10 \mathrm{~A}$ & 02-June-10 \\
\hline RCC 3108 & Rance & $\mathrm{RC} 10 \mathrm{~A}$ & 02-June-10 \\
\hline RCC 3109 & Rance & $\mathrm{RC} 10 \mathrm{~A}$ & 02-June-10 \\
\hline RCC 3110 & Rance & $\mathrm{RC} 10 \mathrm{~A}$ & 02-June-10 \\
\hline RCC 3111 & Rance & $\mathrm{RC} 10 \mathrm{~A}$ & 02-June-10 \\
\hline RCC 3112 & Rance & $\mathrm{RC} 10 \mathrm{~A}$ & 02-June-10 \\
\hline RCC 3113 & Rance & $\mathrm{RC} 10 \mathrm{~A}$ & 02-June-10 \\
\hline RCC 3022 & Rance & $\mathrm{RC} 10 \mathrm{~A}$ & 02-June-10 \\
\hline RCC 3114 & Rance & $\mathrm{RC} 10 \mathrm{~A}$ & 02-June-10 \\
\hline RCC 3115 & Rance & $\mathrm{RC} 10 \mathrm{~A}$ & 02-June-10 \\
\hline RCC 3116 & Rance & $\mathrm{RC} 10 \mathrm{~A}$ & 02-June-10 \\
\hline RCC 3117 & Rance & $\mathrm{RC} 10 \mathrm{~A}$ & 02-June-10 \\
\hline RCC 3118 & Rance & RC10A & 02-June-10 \\
\hline RCC 3119 & Rance & $\mathrm{RC} 10 \mathrm{~A}$ & 02-June-10 \\
\hline RCC 3120 & Rance & $\mathrm{RC} 10 \mathrm{~A}$ & 02-June-10 \\
\hline RCC 3121 & Rance & $\mathrm{RC} 10 \mathrm{~A}$ & 02-June-10 \\
\hline
\end{tabular}




\begin{tabular}{|c|c|c|c|}
\hline RCC 3122 & Rance & $\mathrm{RC} 10 \mathrm{~A}$ & 02-June-10 \\
\hline RCC 3123 & Rance & $\mathrm{RC} 10 \mathrm{~A}$ & 02-June-10 \\
\hline RCC 3124 & Rance & RC10A & 02-June-10 \\
\hline RCC 3125 & Rance & $\mathrm{RC} 10 \mathrm{~A}$ & 02-June-10 \\
\hline RCC 3126 & Rance & $\mathrm{RC} 10 \mathrm{~A}$ & 02-June-10 \\
\hline RCC 3127 & Rance & $\mathrm{RC} 10 \mathrm{~A}$ & 02-June-10 \\
\hline RCC 3128 & Rance & $\mathrm{RC} 10 \mathrm{~A}$ & 02-June-10 \\
\hline RCC 3129 & Rance & RC10A & 02-June-10 \\
\hline RCC 3130 & Rance & $\mathrm{RC} 10 \mathrm{~A}$ & 02-June-10 \\
\hline RCC 3131 & Rance & $\mathrm{RC} 10 \mathrm{~A}$ & 02-June-10 \\
\hline RCC 3132 & Rance & RC10A & 02-June-10 \\
\hline RCC 3133 & Rance & $\mathrm{RC} 10 \mathrm{~A}$ & 02-June-10 \\
\hline RCC 3134 & Rance & $\mathrm{RC} 10 \mathrm{~A}$ & 02-June-10 \\
\hline RCC 3135 & Rance & $\mathrm{RC} 10 \mathrm{~A}$ & 02-June-10 \\
\hline RCC 3136 & Rance & RC10A & 02-June-10 \\
\hline RCC 3137 & Rance & $\mathrm{RC} 10 \mathrm{~A}$ & 02-June-10 \\
\hline RCC 3138 & Rance & $\mathrm{RC} 10 \mathrm{~A}$ & 02-June-10 \\
\hline RCC 3139 & Rance & $\mathrm{RC} 10 \mathrm{~A}$ & 02-June-10 \\
\hline RCC 3140 & Rance & $\mathrm{RC} 10 \mathrm{~A}$ & 02-June-10 \\
\hline RCC 3141 & Rance & $\mathrm{RC} 10 \mathrm{~A}$ & 02-June-10 \\
\hline RCC 3142 & Rance & $\mathrm{RC} 10 \mathrm{~A}$ & 02-June-10 \\
\hline RCC 3143 & Rance & $\mathrm{RC} 10 \mathrm{~A}$ & 02-June-10 \\
\hline RCC 3184 & Rance & $\mathrm{RC} 11 \mathrm{~A}$ & 09-May-11 \\
\hline RCC 3185 & Rance & $\mathrm{RC} 11 \mathrm{~A}$ & 09-Мау-11 \\
\hline RCC 3186 & Rance & RC11A & 09-Мау-11 \\
\hline RCC 3187 & Rance & RC11A & 09-Мay-11 \\
\hline RCC 3188 & Rance & $\mathrm{RC} 11 \mathrm{~A}$ & 09-Мay-11 \\
\hline RCC 3189 & Rance & $\mathrm{RC} 11 \mathrm{~A}$ & 09-May-11 \\
\hline RCC 3190 & Rance & $\mathrm{RC} 11 \mathrm{~A}$ & 09-Мay-11 \\
\hline RCC 3191 & Rance & RC11A & 09-Мay-11 \\
\hline RCC 3192 & Rance & $\mathrm{RC} 11 \mathrm{~A}$ & 09-Мау-11 \\
\hline RCC 3193 & Rance & $\mathrm{RC} 11 \mathrm{~A}$ & 09-Мay-11 \\
\hline RCC 3194 & Rance & $\mathrm{RC} 11 \mathrm{~A}$ & 09-Мау-11 \\
\hline RCC 3195 & Rance & $\mathrm{RC} 11 \mathrm{~A}$ & 09-May-11 \\
\hline RCC 3196 & Rance & RC11A & 09-Мay-11 \\
\hline RCC 3197 & Rance & $\mathrm{RC} 11 \mathrm{~A}$ & 09-Мау-11 \\
\hline RCC 3198 & Rance & RC11A & 09-Мay-11 \\
\hline RCC 3199 & Rance & $\mathrm{RC} 11 \mathrm{~B}$ & 23-May-11 \\
\hline RCC 3200 & Rance & $\mathrm{RC} 11 \mathrm{~B}$ & 23-May-11 \\
\hline RCC 3201 & Rance & $\mathrm{RC} 11 \mathrm{~B}$ & 23-Мay-11 \\
\hline RCC 3202 & Rance & $\mathrm{RC} 11 \mathrm{~B}$ & 23-Мay-11 \\
\hline RCC 3203 & Rance & RC11B & 23-Маy-11 \\
\hline RCC 3204 & Rance & RC11B & 23-Мay-11 \\
\hline RCC 3205 & Rance & $\mathrm{RC} 11 \mathrm{~B}$ & 23-Мау-11 \\
\hline RCC 3206 & Rance & $\mathrm{RC} 11 \mathrm{~B}$ & 23-Мay-11 \\
\hline RCC 3207 & Rance & $\mathrm{RC} 11 \mathrm{~B}$ & 23-Мay-11 \\
\hline RCC 3208 & Rance & RC11B & 23-Мay-11 \\
\hline RCC 3209 & Rance & $\mathrm{RC} 11 \mathrm{~B}$ & 23-May-11 \\
\hline
\end{tabular}




\begin{tabular}{|c|c|c|c|}
\hline RCC 3210 & Rance & $\mathrm{RC} 11 \mathrm{~B}$ & 23-Мay-11 \\
\hline RCC 3211 & Rance & $\mathrm{RC} 11 \mathrm{~B}$ & 23-Мay-11 \\
\hline RCC 3212 & Rance & RC11B & 23-May-11 \\
\hline RCC 3213 & Rance & $\mathrm{RC} 11 \mathrm{~B}$ & 23-Мay-11 \\
\hline RCC 3214 & Rance & $\mathrm{RC} 11 \mathrm{~B}$ & 23-Маy-11 \\
\hline RCC 3215 & Rance & RC11B & 23-Мay-11 \\
\hline RCC 3216 & Rance & $\mathrm{RC} 11 \mathrm{~B}$ & 23-Мay-11 \\
\hline RCC 3217 & Rance & $\mathrm{RC} 11 \mathrm{~B}$ & 23-Мay-11 \\
\hline RCC 3218 & Rance & $\mathrm{RC} 11 \mathrm{~B}$ & 23-Мay-11 \\
\hline RCC 3219 & Rance & RC11B & 23-Мay-11 \\
\hline RCC 3220 & Rance & $\mathrm{RC} 11 \mathrm{~B}$ & 23-Мау-11 \\
\hline RCC 3221 & Rance & $\mathrm{RC} 11 \mathrm{~B}$ & 23-Мay-11 \\
\hline RCC 3222 & Rance & $\mathrm{RC} 11 \mathrm{~B}$ & 23-Мay-11 \\
\hline RCC 3223 & Rance & RC11B & 23-May-11 \\
\hline RCC 3224 & Rance & $\mathrm{RC} 11 \mathrm{C}$ & 27-Мay-11 \\
\hline RCC 3225 & Rance & $\mathrm{RC} 11 \mathrm{C}$ & 27-Маy-11 \\
\hline RCC 3226 & Rance & $\mathrm{RC} 11 \mathrm{C}$ & 27-May-11 \\
\hline RCC 3227 & Rance & $\mathrm{RC} 11 \mathrm{C}$ & 27-Мay-11 \\
\hline RCC 3228 & Rance & $\mathrm{RC} 11 \mathrm{C}$ & 27-May-11 \\
\hline RCC 3229 & Rance & $\mathrm{RC} 11 \mathrm{C}$ & 27-Мay-11 \\
\hline RCC 3230 & Rance & $\mathrm{RC} 11 \mathrm{C}$ & 27-Мay-11 \\
\hline RCC 3231 & Rance & $\mathrm{RC} 11 \mathrm{C}$ & 27-Маy-11 \\
\hline RCC 3232 & Rance & $\mathrm{RC} 11 \mathrm{C}$ & 27-Мay-11 \\
\hline RCC 3233 & Rance & $\mathrm{RC} 11 \mathrm{C}$ & 27-Маy-11 \\
\hline RCC 3234 & Rance & $\mathrm{RC} 11 \mathrm{C}$ & 27-Мay-11 \\
\hline RCC 3235 & Rance & $\mathrm{RC} 11 \mathrm{C}$ & 27-May-11 \\
\hline RCC 3236 & Rance & $\mathrm{RC} 11 \mathrm{C}$ & 27-Мay-11 \\
\hline RCC 3237 & Rance & $\mathrm{RC} 11 \mathrm{C}$ & 27-Мay-11 \\
\hline RCC 3238 & Rance & $\mathrm{RC} 11 \mathrm{C}$ & 27-Мay-11 \\
\hline RCC 3239 & Rance & $\mathrm{RC} 11 \mathrm{C}$ & 27-May-11 \\
\hline RCC 3240 & Rance & $\mathrm{RC} 11 \mathrm{C}$ & 27-May-11 \\
\hline RCC 3241 & Rance & $\mathrm{RC} 11 \mathrm{C}$ & 27-Мау-11 \\
\hline RCC 3242 & Rance & $\mathrm{RC} 11 \mathrm{C}$ & 27-Мау-11 \\
\hline RCC 3243 & Rance & $\mathrm{RC} 11 \mathrm{C}$ & 27-May-11 \\
\hline RCC 3244 & Rance & $\mathrm{RC} 11 \mathrm{C}$ & 27-Мay-11 \\
\hline RCC 3245 & Rance & $\mathrm{RC} 11 \mathrm{C}$ & 27-Мay-11 \\
\hline RCC 3246 & Rance & $\mathrm{RC} 11 \mathrm{C}$ & 27-Мay-11 \\
\hline RCC 3247 & Rance & $\mathrm{RC} 11 \mathrm{C}$ & 27-Мay-11 \\
\hline RCC 3248 & Rance & $\mathrm{RC} 11 \mathrm{C}$ & 27-May-11 \\
\hline RCC 3268 & Rance & RC11D & 03-June-11 \\
\hline RCC 3269 & Rance & $\mathrm{RC} 11 \mathrm{D}$ & 03-June-11 \\
\hline RCC 3270 & Rance & RC11D & 03-June-11 \\
\hline RCC 3271 & Rance & RC11D & 03-June-11 \\
\hline RCC 3272 & Rance & RC11D & 03-June-11 \\
\hline RCC 3273 & Rance & RC11D & 03-June-11 \\
\hline RCC 3274 & Rance & RC11D & 03-June-11 \\
\hline RCC 3275 & Rance & RC11D & 03-June-11 \\
\hline RCC 3276 & Rance & RC11D & 03-June-11 \\
\hline
\end{tabular}




\begin{tabular}{llll} 
RCC 3277 & Rance & RC11D & 03-June-11 \\
RCC 3278 & Rance & RC11D & 05-June-11 \\
RCC 3279 & Rance & RC11D & 05-June-11 \\
RCC 3280 & Rance & RC11D & 05-June-11 \\
RCC 3281 & Rance & RC11D & 05-June-11 \\
RCC 3282 & Rance & RC11D & 05-June-11 \\
RCC 3283 & Rance & RC11D & 05-June-11 \\
RCC 3284 & Rance & RC11D & 05-June-11 \\
RCC 3285 & Rance & RC11D & 05-June-11 \\
RCC 3286 & Rance & RC11D & 05-June-11 \\
RCC 3287 & Rance & RC11D & 05-June-11 \\
RCC 3288 & Rance & RC11D & 05-June-11 \\
RCC 3289 & Rance & RC11D & 05-June-11 \\
RCC 3290 & Rance & RC11D & 05-June-11 \\
RCC 3291 & Rance & RC11D & 05-June-11 \\
RCC 3292 & Rance & RC11D & 05-June-11 \\
RCC 3293 & Rance & RC11D & 05-June-11 \\
RCC 3294 & Rance & RC11D & 05-June-11 \\
RCC 3295 & Rance & RC11D & 05-June-11 \\
RCC 3296 & Rance & RC11D & 05-June-11 \\
\hline
\end{tabular}


Table S2. Microsatellite data amplified on 265 individual strains at seven loci. Population codes are given in Table 1.

\begin{tabular}{|c|c|c|c|c|c|c|c|c|}
\hline Individuals & $\begin{array}{l}\text { Sample } \\
\text { codes }\end{array}$ & Aminu22 & Aminu41 & Aminu11 & Aminu20 & Aminu43 & Aminu48 & Aminu08 \\
\hline PZ374 & PZ10A & 199 & 202 & 255 & 0 & 201 & 215 & 185 \\
\hline PZ352 & PZ10A & 199 & 200 & 228 & 279 & 201 & 0 & 190 \\
\hline PZ330 & PZ10A & 197 & 164 & 240 & 248 & 0 & 0 & 180 \\
\hline PZ350 & PZ10A & 197 & 202 & 228 & 279 & 0 & 176 & 185 \\
\hline PZ344 & PZ10A & 197 & 200 & 228 & 0 & 215 & 217 & 185 \\
\hline PZ341 & PZ10A & 197 & 232 & 248 & 248 & 230 & 234 & 185 \\
\hline PZ362 & PZ10A & 197 & 200 & 238 & 279 & 188 & 0 & 190 \\
\hline PZ339 & PZ10A & 197 & 232 & 0 & 0 & 202 & 0 & 190 \\
\hline PZ351 & PZ10A & 197 & 202 & 236 & 250 & 197 & 214 & 190 \\
\hline PZ359 & PZ10A & 197 & 162 & 240 & 279 & 188 & 0 & 199 \\
\hline PZ331 & PZ10A & 195 & 202 & 236 & 0 & 205 & 240 & 187 \\
\hline PZ360 & PZ10A & 179 & 0 & 236 & 279 & 221 & 0 & 190 \\
\hline PZ353 & PZ10A & 0 & 218 & 0 & 279 & 220 & 0 & 185 \\
\hline PZ345 & PZ10A & 0 & 0 & 287 & 0 & 188 & 252 & 185 \\
\hline PZ355 & PZ10A & 0 & 232 & 248 & 279 & 221 & 176 & 190 \\
\hline PZ356 & PZ10A & 0 & 207 & 238 & 279 & 197 & 214 & 190 \\
\hline PZ340 & PZ10A & 0 & 163 & 248 & 279 & 188 & 176 & 197 \\
\hline PZ333 & PZ10A & 195 & 202 & 237 & 236 & 200 & 239 & 187 \\
\hline PZ334 & PZ10A & 197 & 200 & 238 & 253 & 204 & 239 & 189 \\
\hline PZ337 & PZ10A & 197 & 202 & 255 & 273 & 189 & 240 & 191 \\
\hline PZ338 & PZ10A & 199 & 202 & 239 & 269 & 0 & 242 & 0 \\
\hline PZ348 & PZ10A & 199 & 204 & 242 & 265 & 0 & 240 & 189 \\
\hline PZ354 & PZ10A & 197 & 206 & 229 & 267 & 187 & 238 & 0 \\
\hline PZ369 & PZ10A & 197 & 202 & 267 & 247 & 0 & 206 & 174 \\
\hline PZ482 & PZ10D & 201 & 200 & 244 & 271 & 197 & 239 & 179 \\
\hline PZ484 & PZ10D & 197 & 204 & 229 & 261 & 204 & 0 & 184 \\
\hline PZ485 & PZ10D & 199 & 204 & 225 & 263 & 200 & 231 & 216 \\
\hline PZ487 & PZ10D & 199 & 200 & 225 & 0 & 211 & 232 & 226 \\
\hline PZ488 & PZ10D & 199 & 204 & 225 & 248 & 200 & 234 & 216 \\
\hline PZ489 & PZ10D & 0 & 0 & 225 & 231 & 0 & 210 & 0 \\
\hline PZ491 & PZ10D & 197 & 204 & 239 & 261 & 197 & 248 & 0 \\
\hline PZ492 & PZ10D & 197 & 200 & 249 & 251 & 200 & 0 & 187 \\
\hline PZ493 & PZ10D & 168 & 202 & 240 & 0 & 187 & 228 & 220 \\
\hline PZ520 & PZ10D & 199 & 200 & 242 & 260 & 190 & 240 & 185 \\
\hline PZ521 & PZ10D & 197 & 200 & 252 & 262 & 202 & 242 & 194 \\
\hline PZ524 & PZ10D & 195 & 202 & 242 & 248 & 205 & 239 & 185 \\
\hline PZ514 & PZ10D & 195 & 202 & 258 & 0 & 197 & 239 & 190 \\
\hline PZ509 & PZ10D & 182 & 202 & 242 & 261 & 198 & 225 & 190 \\
\hline PZ500 & PZ10D & 179 & 202 & 240 & 261 & 206 & 218 & 187 \\
\hline PZ516 & PZ10D & 0 & 200 & 0 & 279 & 206 & 229 & 199 \\
\hline
\end{tabular}




\begin{tabular}{|c|c|c|c|c|c|c|c|c|}
\hline PZ522 & PZ10D & 199 & 200 & 240 & 263 & 187 & 240 & 216 \\
\hline PZ579 & PZ11A & 182 & 200 & 228 & 0 & 204 & 239 & 0 \\
\hline PZ594 & PZ11A & 197 & 202 & 228 & 248 & 199 & 234 & 194 \\
\hline PZ582 & PZ11A & 197 & 200 & 228 & 273 & 202 & 239 & 190 \\
\hline PZ591 & PZ11A & 197 & 202 & 237 & 0 & 194 & 239 & 187 \\
\hline PZ584 & PZ11A & 197 & 202 & 257 & 259 & 196 & 239 & 185 \\
\hline PZ593 & PZ11A & 197 & 200 & 248 & 0 & 202 & 237 & 179 \\
\hline PZ587 & PZ11A & 199 & 202 & 236 & 0 & 201 & 239 & 190 \\
\hline PZ589 & PZ11A & 199 & 202 & 259 & 261 & 209 & 244 & 185 \\
\hline PZ583 & PZ11A & 199 & 200 & 242 & 0 & 207 & 239 & 185 \\
\hline PZ572 & PZ11A & 197 & 200 & 257 & 261 & 204 & 256 & 234 \\
\hline PZ575 & PZ11A & 0 & 0 & 240 & 0 & 202 & 235 & 187 \\
\hline PZ577 & PZ11A & 0 & 206 & 0 & 265 & 171 & 242 & 186 \\
\hline PZ578 & PZ11A & 0 & 0 & 239 & 0 & 206 & 239 & 217 \\
\hline PZ580 & PZ11A & 197 & 202 & 242 & 253 & 197 & 236 & 225 \\
\hline PZ581 & PZ11A & 197 & 202 & 237 & 237 & 202 & 240 & 189 \\
\hline PZ586 & PZ11A & 0 & 202 & 259 & 261 & 208 & 244 & 189 \\
\hline PZ590 & PZ11A & 0 & 155 & 240 & 0 & 0 & 229 & 187 \\
\hline PZ595 & PZ11A & 210 & 200 & 236 & 265 & 204 & 234 & 0 \\
\hline PZ597 & PZ11A & 197 & 200 & 0 & 0 & 198 & 241 & 191 \\
\hline PZ689 & PZ11B & 197 & 202 & 239 & 269 & 0 & 251 & 179 \\
\hline PZ691 & PZ11B & 197 & 200 & 229 & 267 & 196 & 239 & 210 \\
\hline PZ696 & PZ11B & 194 & 202 & 259 & 259 & 198 & 239 & 0 \\
\hline PZ697 & PZ11B & 197 & 200 & 237 & 270 & 200 & 242 & 187 \\
\hline PZ701 & PZ11B & 195 & 202 & 239 & 274 & 196 & 238 & 189 \\
\hline PZ704 & PZ11B & 195 & 200 & 257 & 261 & 197 & 239 & 187 \\
\hline PZ708 & PZ11B & 199 & 200 & 229 & 261 & 197 & 239 & 226 \\
\hline PZ711 & PZ11B & 197 & 0 & 242 & 263 & 198 & 241 & 184 \\
\hline PZ712 & PZ11B & 0 & 176 & 242 & 259 & 204 & 241 & 197 \\
\hline PZ714 & PZ11B & 195 & 196 & 229 & 265 & 212 & 210 & 179 \\
\hline PZ715 & PZ11B & 195 & 202 & 248 & 253 & 206 & 218 & 0 \\
\hline PZ716 & PZ11B & 197 & 202 & 248 & 283 & 204 & 240 & 200 \\
\hline PZ719 & PZ11B & 197 & 202 & 239 & 253 & 204 & 0 & 187 \\
\hline PZ721 & PZ11B & 197 & 200 & 239 & 264 & 201 & 240 & 201 \\
\hline PZ742 & PZ11B & 197 & 200 & 239 & 262 & 202 & 240 & 190 \\
\hline PZ743 & PZ11B & 199 & 202 & 229 & 0 & 200 & 240 & 189 \\
\hline PZ749 & PZ11B & 212 & 202 & 237 & 261 & 204 & 239 & 187 \\
\hline PZ959 & PZ11B & 197 & 196 & 248 & 261 & 206 & 0 & 189 \\
\hline PZ960 & PZ11B & 197 & 200 & 229 & 265 & 202 & 246 & 189 \\
\hline PZ961 & PZ11B & 193 & 202 & 257 & 257 & 210 & 240 & 189 \\
\hline PZ962 & PZ11B & 195 & 200 & 223 & 248 & 0 & 246 & 187 \\
\hline PZ963 & PZ11B & 197 & 202 & 238 & 248 & 204 & 240 & 211 \\
\hline PZ964 & PZ11B & 197 & 232 & 227 & 271 & 0 & 240 & 187 \\
\hline PZ965 & PZ11B & 0 & 223 & 244 & 265 & 202 & 240 & 184 \\
\hline
\end{tabular}




\begin{tabular}{|c|c|c|c|c|c|c|c|c|}
\hline PZ966 & PZ11B & 197 & 202 & 248 & 273 & 0 & 0 & 198 \\
\hline PZ967 & PZ11B & 0 & 0 & 0 & 274 & 208 & 240 & 208 \\
\hline PZ968 & PZ11B & 192 & 202 & 252 & 269 & 194 & 248 & 189 \\
\hline PZ969 & PZ11B & 196 & 210 & 229 & 279 & 200 & 0 & 189 \\
\hline PZ970 & PZ11B & 200 & 200 & 229 & 279 & 0 & 246 & 189 \\
\hline PZ788 & PZ11C & 200 & 200 & 236 & 0 & 198 & 239 & 190 \\
\hline PZ770 & PZ11C & 199 & 200 & 248 & 258 & 188 & 240 & 187 \\
\hline PZ753 & $\mathrm{PZ11C}$ & 199 & 202 & 228 & 253 & 205 & 242 & 190 \\
\hline PZ761 & PZ11C & 197 & 202 & 257 & 263 & 201 & 237 & 201 \\
\hline PZ764 & PZ11C & 195 & 202 & 0 & 264 & 203 & 240 & 185 \\
\hline PZ789 & PZ11C & 195 & 200 & 259 & 0 & 198 & 242 & 187 \\
\hline PZ754 & PZ11C & 190 & 200 & 236 & 267 & 204 & 239 & 174 \\
\hline PZ757 & PZ11C & 195 & 200 & 237 & 259 & 191 & 239 & 189 \\
\hline PZ758 & PZ11C & 195 & 200 & 226 & 269 & 204 & 242 & 184 \\
\hline PZ759 & PZ11C & 199 & 202 & 242 & 263 & 0 & 0 & 0 \\
\hline PZ762 & PZ11C & 195 & 202 & 229 & 267 & 208 & 239 & 187 \\
\hline PZ766 & PZ11C & 199 & 200 & 242 & 269 & 202 & 239 & 187 \\
\hline PZ767 & PZ11C & 0 & 202 & 0 & 265 & 212 & 239 & 184 \\
\hline PZ771 & PZ11C & 199 & 202 & 229 & 0 & 200 & 239 & 189 \\
\hline PZ773 & PZ11C & 197 & 200 & 229 & 273 & 198 & 233 & 189 \\
\hline PZ775 & PZ11C & 195 & 204 & 229 & 259 & 197 & 231 & 192 \\
\hline PZ777 & $\mathrm{PZ11C}$ & 199 & 200 & 242 & 257 & 208 & 241 & 225 \\
\hline PZ778 & PZ11C & 197 & 202 & 229 & 261 & 206 & 241 & 198 \\
\hline PZ780 & PZ11C & 204 & 200 & 236 & 0 & 200 & 241 & 225 \\
\hline PZ781 & PZ11C & 195 & 200 & 228 & 261 & 208 & 239 & 189 \\
\hline PZ782 & PZ11C & 199 & 202 & 238 & 270 & 204 & 242 & 189 \\
\hline PZ784 & PZ11C & 197 & 200 & 229 & 0 & 198 & 256 & 189 \\
\hline PZ785 & PZ11C & 199 & 202 & 244 & 270 & 198 & 240 & 187 \\
\hline PZ787 & PZ11C & 199 & 202 & 239 & 271 & 204 & 242 & 184 \\
\hline PZ665 & PZ11D & 199 & 210 & 242 & 248 & 209 & 242 & 0 \\
\hline PZ661 & PZ11D & 199 & 202 & 253 & 248 & 192 & 239 & 187 \\
\hline PZ645 & PZ11D & 199 & 202 & 228 & 248 & 207 & 237 & 190 \\
\hline PZ648 & PZ11D & 197 & 200 & 228 & 248 & 197 & 239 & 0 \\
\hline PZ682 & PZ11D & 197 & 202 & 252 & 0 & 203 & 239 & 0 \\
\hline PZ643 & PZ11D & 197 & 202 & 244 & 270 & 200 & 239 & 190 \\
\hline PZ679 & PZ11D & 197 & 200 & 228 & 254 & 207 & 240 & 207 \\
\hline PZ660 & PZ11D & 183 & 200 & 248 & 248 & 0 & 239 & 227 \\
\hline PZ655 & PZ11D & 0 & 202 & 0 & 248 & 0 & 236 & 190 \\
\hline PZ637 & PZ11D & 197 & 200 & 239 & 248 & 200 & 229 & 233 \\
\hline PZ639 & PZ11D & 198 & 0 & 237 & 269 & 199 & 239 & 229 \\
\hline PZ640 & PZ11D & 199 & 200 & 255 & 253 & 200 & 229 & 211 \\
\hline PZ641 & PZ11D & 197 & 202 & 242 & 257 & 204 & 242 & 221 \\
\hline PZ644 & PZ11D & 199 & 200 & 239 & 269 & 200 & 239 & 189 \\
\hline PZ646 & PZ11D & 197 & 200 & 248 & 261 & 204 & 229 & 0 \\
\hline PZ647 & PZ11D & 207 & 200 & 242 & 271 & 0 & 239 & 187 \\
\hline
\end{tabular}




\begin{tabular}{|c|c|c|c|c|c|c|c|c|}
\hline PZ658 & PZ11D & 0 & 162 & 238 & 263 & 0 & 260 & 237 \\
\hline PZ683 & PZ11D & 197 & 210 & 229 & 274 & 204 & 240 & 185 \\
\hline $\mathrm{RC} 275$ & RC10A & 0 & 0 & 208 & 279 & 214 & 214 & 0 \\
\hline $\mathrm{RC} 277$ & $\mathrm{RC} 10 \mathrm{~A}$ & 195 & 200 & 229 & 261 & 202 & 239 & 192 \\
\hline RC280 & RC10A & 207 & 202 & 238 & 237 & 175 & 235 & 184 \\
\hline $\mathrm{RC} 281$ & $\mathrm{RC} 10 \mathrm{~A}$ & 197 & 200 & 223 & 0 & 202 & 241 & 175 \\
\hline RC283 & RC10A & 197 & 204 & 229 & 255 & 202 & 250 & 189 \\
\hline $\mathrm{RC} 297$ & $\mathrm{RC} 10 \mathrm{~A}$ & 197 & 215 & 249 & 271 & 202 & 211 & 213 \\
\hline RC304 & RC10A & 182 & 226 & 251 & 0 & 0 & 231 & 213 \\
\hline $\mathrm{RC} 322$ & $\mathrm{RC} 10 \mathrm{~A}$ & 183 & 199 & 224 & 259 & 175 & 0 & 187 \\
\hline $\mathrm{RC} 317$ & $\mathrm{RC} 10 \mathrm{~A}$ & 202 & 202 & 238 & 0 & 0 & 176 & 205 \\
\hline RC307 & RC10A & 197 & 200 & 238 & 248 & 0 & 0 & 0 \\
\hline RC321 & $\mathrm{RC} 10 \mathrm{~A}$ & 197 & 204 & 236 & 0 & 194 & 0 & 0 \\
\hline $\mathrm{RC} 271$ & $\mathrm{RC} 10 \mathrm{~A}$ & 197 & 200 & 248 & 279 & 188 & 176 & 0 \\
\hline RC293 & $\mathrm{RC} 10 \mathrm{~A}$ & 197 & 210 & 242 & 261 & 198 & 240 & 0 \\
\hline RC323 & RC10A & 197 & 200 & 0 & 279 & 180 & 217 & 180 \\
\hline RC301 & RC10A & 197 & 200 & 278 & 0 & 0 & 226 & 185 \\
\hline RC316 & RC10A & 197 & 202 & 244 & 0 & 0 & 214 & 187 \\
\hline RC311 & RC10A & 197 & 202 & 248 & 248 & 188 & 176 & 199 \\
\hline RC310 & $\mathrm{RC} 10 \mathrm{~A}$ & 197 & 200 & 0 & 246 & 188 & 180 & 205 \\
\hline RC315 & RC10A & 197 & 202 & 0 & 0 & 0 & 240 & 205 \\
\hline RC296 & $\mathrm{RC} 10 \mathrm{~A}$ & 197 & 200 & 240 & 248 & 0 & 214 & 213 \\
\hline RC325 & RC10A & 197 & 200 & 278 & 279 & 184 & 176 & 230 \\
\hline RC327 & $\mathrm{RC} 10 \mathrm{~A}$ & 195 & 202 & 240 & 279 & 221 & 176 & 0 \\
\hline RC295 & RC10A & 195 & 202 & 228 & 248 & 0 & 226 & 0 \\
\hline RC298 & $\mathrm{RC} 10 \mathrm{~A}$ & 195 & 200 & 248 & 0 & 0 & 240 & 0 \\
\hline RC305 & RC10A & 195 & 202 & 238 & 0 & 198 & 181 & 185 \\
\hline RC313 & RC10A & 195 & 200 & 248 & 248 & 0 & 214 & 205 \\
\hline RC308 & $\mathrm{RC} 10 \mathrm{~A}$ & 195 & 0 & 0 & 0 & 0 & 240 & 205 \\
\hline RC303 & RC10A & 193 & 200 & 0 & 0 & 201 & 181 & 185 \\
\hline RC314 & $\mathrm{RC} 10 \mathrm{~A}$ & 193 & 0 & 0 & 0 & 217 & 214 & 190 \\
\hline RC324 & $\mathrm{RC} 10 \mathrm{~A}$ & 193 & 204 & 238 & 279 & 188 & 176 & 205 \\
\hline RC328 & $\mathrm{RC} 10 \mathrm{~A}$ & 190 & 200 & 238 & 279 & 180 & 176 & 185 \\
\hline $\mathrm{RC} 287$ & RC10A & 182 & 200 & 0 & 265 & 213 & 176 & 0 \\
\hline RC300 & RC10A & 182 & 0 & 238 & 248 & 221 & 236 & 0 \\
\hline $\mathrm{RC} 282$ & RC10A & 182 & 181 & 248 & 279 & 0 & 176 & 199 \\
\hline RC302 & $\mathrm{RC} 10 \mathrm{~A}$ & 156 & 218 & 240 & 0 & 203 & 226 & 0 \\
\hline RC294 & $\mathrm{RC} 10 \mathrm{~A}$ & 0 & 202 & 236 & 248 & 196 & 214 & 0 \\
\hline $\mathrm{RC} 273$ & RC10A & 0 & 210 & 278 & 279 & 188 & 176 & 190 \\
\hline RC292 & $\mathrm{RC} 10 \mathrm{~A}$ & 0 & 200 & 223 & 0 & 201 & 214 & 197 \\
\hline RC320 & RC10A & 0 & 223 & 248 & 0 & 188 & 176 & 199 \\
\hline RC326 & RC10A & 0 & 210 & 223 & 0 & 220 & 176 & 205 \\
\hline RC913 & RC11A & 195 & 200 & 244 & 261 & 0 & 237 & 189 \\
\hline RC915 & RC11A & 193 & 0 & 229 & 0 & 200 & 240 & 221 \\
\hline RC922 & $\mathrm{RC} 11 \mathrm{~A}$ & 193 & 202 & 229 & 259 & 196 & 240 & 185 \\
\hline
\end{tabular}




\begin{tabular}{|c|c|c|c|c|c|c|c|c|}
\hline RC925 & $\mathrm{RC} 11 \mathrm{~A}$ & 200 & 200 & 239 & 259 & 196 & 231 & 208 \\
\hline RC931 & $\mathrm{RC} 11 \mathrm{~A}$ & 197 & 202 & 239 & 255 & 206 & 240 & 191 \\
\hline RC937 & $\mathrm{RC} 11 \mathrm{~A}$ & 197 & 204 & 248 & 261 & 201 & 240 & 189 \\
\hline RC938 & $\mathrm{RC} 11 \mathrm{~A}$ & 197 & 202 & 242 & 269 & 200 & 243 & 184 \\
\hline RC939 & $\mathrm{RC} 11 \mathrm{~A}$ & 195 & 200 & 238 & 261 & 193 & 240 & 206 \\
\hline RC919 & $\mathrm{RC} 11 \mathrm{~A}$ & 197 & 202 & 236 & 259 & 198 & 240 & 185 \\
\hline RC921 & $\mathrm{RC} 11 \mathrm{~A}$ & 0 & 200 & 253 & 248 & 203 & 237 & 187 \\
\hline RC926 & $\mathrm{RC} 11 \mathrm{~A}$ & 0 & 200 & 250 & 248 & 205 & 239 & 0 \\
\hline RC927 & $\mathrm{RC} 11 \mathrm{~A}$ & 197 & 200 & 237 & 0 & 205 & 239 & 0 \\
\hline RC930 & $\mathrm{RC} 11 \mathrm{~A}$ & 197 & 200 & 238 & 0 & 205 & 240 & 172 \\
\hline RC932 & $\mathrm{RC} 11 \mathrm{~A}$ & 199 & 0 & 0 & 0 & 203 & 240 & 213 \\
\hline RC934 & $\mathrm{RC} 11 \mathrm{~A}$ & 0 & 0 & 238 & 248 & 203 & 240 & 210 \\
\hline $\mathrm{RC} 1003$ & $\mathrm{RC} 11 \mathrm{~B}$ & 197 & 200 & 248 & 253 & 202 & 0 & 188 \\
\hline RC1013 & $\mathrm{RC} 11 \mathrm{~B}$ & 197 & 200 & 239 & 268 & 204 & 238 & 187 \\
\hline RC1014 & RC11B & 0 & 202 & 239 & 271 & 200 & 240 & 225 \\
\hline RC1016 & $\mathrm{RC} 11 \mathrm{~B}$ & 199 & 200 & 0 & 258 & 200 & 239 & 187 \\
\hline RC974 & $\mathrm{RC} 11 \mathrm{~B}$ & 197 & 202 & 236 & 0 & 200 & 240 & 224 \\
\hline RC975 & $\mathrm{RC} 11 \mathrm{~B}$ & 197 & 200 & 238 & 265 & 198 & 328 & 187 \\
\hline RC978 & $\mathrm{RC} 11 \mathrm{~B}$ & 199 & 202 & 229 & 263 & 201 & 0 & 0 \\
\hline RC979 & $\mathrm{RC} 11 \mathrm{~B}$ & 200 & 200 & 229 & 255 & 0 & 0 & 216 \\
\hline RC980 & $\mathrm{RC} 11 \mathrm{~B}$ & 197 & 200 & 238 & 253 & 0 & 240 & 189 \\
\hline RC981 & $\mathrm{RC} 11 \mathrm{~B}$ & 197 & 200 & 263 & 278 & 195 & 240 & 187 \\
\hline RC982 & $\mathrm{RC} 11 \mathrm{~B}$ & 195 & 200 & 245 & 269 & 200 & 242 & 187 \\
\hline RC983 & RC11B & 197 & 202 & 239 & 261 & 202 & 242 & 187 \\
\hline RC984 & $\mathrm{RC} 11 \mathrm{~B}$ & 197 & 200 & 239 & 261 & 207 & 0 & 0 \\
\hline RC986 & RC11B & 197 & 210 & 244 & 269 & 202 & 240 & 197 \\
\hline RC987 & RC11B & 199 & 202 & 240 & 252 & 198 & 240 & 184 \\
\hline RC988 & $\mathrm{RC} 11 \mathrm{~B}$ & 195 & 196 & 229 & 0 & 191 & 236 & 216 \\
\hline RC992 & $\mathrm{RC} 11 \mathrm{~B}$ & 197 & 200 & 237 & 259 & 0 & 240 & 187 \\
\hline RC999 & $\mathrm{RC} 11 \mathrm{~B}$ & 197 & 202 & 237 & 261 & 209 & 240 & 205 \\
\hline RC1008 & $\mathrm{RC} 11 \mathrm{~B}$ & 197 & 200 & 238 & 258 & 203 & 239 & 172 \\
\hline RC1001 & RC11B & 197 & 162 & 244 & 0 & 205 & 239 & 185 \\
\hline RC1005 & $\mathrm{RC} 11 \mathrm{~B}$ & 197 & 200 & 240 & 258 & 198 & 244 & 190 \\
\hline RC1015 & $\mathrm{RC} 11 \mathrm{~B}$ & 191 & 200 & 0 & 0 & 218 & 230 & 230 \\
\hline RC994 & $\mathrm{RC} 11 \mathrm{~B}$ & 188 & 0 & 248 & 259 & 194 & 239 & 230 \\
\hline RC991 & $\mathrm{RC} 11 \mathrm{~B}$ & 180 & 0 & 229 & 269 & 197 & 0 & 187 \\
\hline RC1011 & RC11B & 0 & 208 & 255 & 273 & 203 & 239 & 185 \\
\hline RC1019 & RC11C & 194 & 223 & 239 & 0 & 0 & 242 & 199 \\
\hline RC1020 & $\mathrm{RC} 11 \mathrm{C}$ & 0 & 200 & 242 & 0 & 0 & 258 & 187 \\
\hline RC1021 & $\mathrm{RC} 11 \mathrm{C}$ & 197 & 202 & 236 & 259 & 198 & 242 & 184 \\
\hline $\mathrm{RC} 1022$ & $\mathrm{RC} 11 \mathrm{C}$ & 197 & 202 & 257 & 267 & 202 & 240 & 216 \\
\hline RC1024 & RC11C & 197 & 202 & 237 & 261 & 200 & 242 & 201 \\
\hline RC1026 & $\mathrm{RC} 11 \mathrm{C}$ & 197 & 196 & 237 & 273 & 0 & 240 & 206 \\
\hline RC1028 & $\mathrm{RC} 11 \mathrm{C}$ & 0 & 200 & 198 & 261 & 204 & 240 & 195 \\
\hline RC1032 & $\mathrm{RC} 11 \mathrm{C}$ & 0 & 212 & 224 & 0 & 196 & 238 & 184 \\
\hline
\end{tabular}




\begin{tabular}{|c|c|c|c|c|c|c|c|c|}
\hline RC1034 & $\mathrm{RC} 11 \mathrm{C}$ & 197 & 218 & 228 & 275 & 202 & 226 & 202 \\
\hline RC1040 & $\mathrm{RC} 11 \mathrm{C}$ & 229 & 0 & 230 & 0 & 202 & 233 & 189 \\
\hline RC1042 & $\mathrm{RC} 11 \mathrm{C}$ & 197 & 200 & 237 & 255 & 197 & 233 & 189 \\
\hline RC1043 & $\mathrm{RC} 11 \mathrm{C}$ & 197 & 200 & 239 & 261 & 0 & 242 & 187 \\
\hline $\mathrm{RC} 1044$ & $\mathrm{RC} 11 \mathrm{C}$ & 200 & 200 & 237 & 255 & 200 & 247 & 191 \\
\hline RC1047 & $\mathrm{RC} 11 \mathrm{C}$ & 197 & 0 & 248 & 251 & 202 & 238 & 176 \\
\hline RC1049 & $\mathrm{RC} 11 \mathrm{C}$ & 0 & 180 & 237 & 263 & 196 & 238 & 187 \\
\hline $\mathrm{RC} 1050$ & $\mathrm{RC} 11 \mathrm{C}$ & 197 & 0 & 229 & 269 & 200 & 242 & 164 \\
\hline RC1055 & $\mathrm{RC} 11 \mathrm{C}$ & 197 & 0 & 229 & 276 & 200 & 238 & 216 \\
\hline RC1059 & $\mathrm{RC} 11 \mathrm{C}$ & 197 & 197 & 255 & 0 & 204 & 240 & 216 \\
\hline RC1061 & $\mathrm{RC} 11 \mathrm{C}$ & 215 & 0 & 239 & 0 & 0 & 244 & 175 \\
\hline RC1062 & $\mathrm{RC} 11 \mathrm{C}$ & 197 & 0 & 239 & 265 & 193 & 218 & 187 \\
\hline RC1035 & $\mathrm{RC} 11 \mathrm{C}$ & 195 & 204 & 252 & 0 & 197 & 242 & 185 \\
\hline RC1036 & $\mathrm{RC} 11 \mathrm{C}$ & 183 & 210 & 236 & 261 & 0 & 242 & 172 \\
\hline RC1056 & $\mathrm{RC} 11 \mathrm{C}$ & 206 & 200 & 253 & 253 & 205 & 242 & 0 \\
\hline RC1039 & $\mathrm{RC} 11 \mathrm{C}$ & 197 & 202 & 242 & 253 & 207 & 239 & 187 \\
\hline RC1060 & $\mathrm{RC} 11 \mathrm{C}$ & 195 & 202 & 252 & 258 & 202 & 240 & 187 \\
\hline RC854 & RC11D & 197 & 202 & 248 & 0 & 0 & 242 & 187 \\
\hline RC855 & RC11D & 197 & 224 & 241 & 260 & 204 & 240 & 189 \\
\hline RC857 & RC11D & 197 & 200 & 237 & 265 & 0 & 238 & 194 \\
\hline RC858 & RC11D & 0 & 0 & 243 & 0 & 202 & 235 & 195 \\
\hline RC859 & RC11D & 196 & 0 & 229 & 267 & 202 & 0 & 180 \\
\hline RC860 & $\mathrm{RC} 11 \mathrm{D}$ & 198 & 202 & 255 & 261 & 196 & 240 & 0 \\
\hline RC861 & RC11D & 197 & 0 & 255 & 261 & 196 & 240 & 190 \\
\hline RC863 & $\mathrm{RC} 11 \mathrm{D}$ & 195 & 202 & 239 & 267 & 201 & 240 & 190 \\
\hline RC864 & RC11D & 197 & 202 & 237 & 285 & 0 & 240 & 185 \\
\hline RC867 & $\mathrm{RC} 11 \mathrm{D}$ & 197 & 0 & 239 & 267 & 0 & 257 & 187 \\
\hline RC873 & RC11D & 197 & 200 & 257 & 0 & 0 & 240 & 187 \\
\hline RC874 & RC11D & 195 & 200 & 248 & 267 & 199 & 240 & 187 \\
\hline RC875 & RC11D & 207 & 202 & 259 & 261 & 204 & 240 & 180 \\
\hline RC876 & RC11D & 202 & 202 & 0 & 0 & 204 & 0 & 190 \\
\hline RC877 & RC11D & 197 & 202 & 251 & 259 & 191 & 240 & 187 \\
\hline RC878 & RC11D & 200 & 201 & 237 & 253 & 0 & 264 & 190 \\
\hline RC880 & $\mathrm{RC} 11 \mathrm{D}$ & 197 & 202 & 238 & 238 & 0 & 242 & 227 \\
\hline RC881 & $\mathrm{RC} 11 \mathrm{D}$ & 197 & 202 & 238 & 271 & 208 & 237 & 187 \\
\hline RC884 & $\mathrm{RC} 11 \mathrm{D}$ & 195 & 202 & 257 & 267 & 204 & 240 & 187 \\
\hline RC885 & RC11D & 197 & 202 & 237 & 261 & 0 & 240 & 222 \\
\hline RC889 & RC11D & 0 & 204 & 243 & 261 & 201 & 228 & 179 \\
\hline RC894 & RC11D & 197 & 200 & 229 & 251 & 193 & 240 & 187 \\
\hline RC895 & $\mathrm{RC} 11 \mathrm{D}$ & 196 & 200 & 239 & 262 & 193 & 240 & 187 \\
\hline RC897 & RC11D & 196 & 200 & 243 & 262 & 201 & 242 & 185 \\
\hline RC898 & RC11D & 195 & 200 & 237 & 261 & 0 & 240 & 185 \\
\hline RC883 & RC11D & 197 & 202 & 236 & 0 & 205 & 239 & 190 \\
\hline RC886 & RC11D & 197 & 202 & 236 & 0 & 199 & 240 & 190 \\
\hline
\end{tabular}




\begin{tabular}{lllllllll} 
RC887 & RC11D & 191 & 200 & 242 & 255 & 205 & 239 & 174 \\
RC882 & RC11D & 197 & 0 & 236 & 255 & 197 & 239 & 187 \\
\hline
\end{tabular}


Table S3: Pairwise differentiation between the 11 populations of Alexandrium minitum. $F_{\mathrm{st}}(\theta)$ values are given above diagonal and Jost's $\mathrm{D}_{\mathrm{est}}$ below diagonal. Significant $F_{\text {st }}$ values (1000 permutations) are depicted in bold. *: $F_{\text {st }}$ values that remain significant after a Bonferroni correction. Population codes are given in Table 1.

\begin{tabular}{|c|c|c|c|c|c|c|c|c|c|c|c|}
\hline & PZ10A & PZ10D & PZ11A & PZ11B & PZ11C & PZ11D & RC10A & RC11A & RC11B & RC11C & RC11D \\
\hline PZ10A & & 0.0396 & 0.0265 & 0.0378* & 0.0639* & 0.0403 & 0.0161 & 0.0577 & $0.0456^{*}$ & $0.0443^{*}$ & $0.0486^{*}$ \\
\hline PZ10D & 0.3228 & & 0.0124 & 0.0247 & 0.0170 & 0.0122 & $0.0495^{*}$ & 0.0281 & 0.0234 & 0.0254 & $0.0495^{*}$ \\
\hline PZ11B & 0.2748 & 0.2279 & 0.0929 & & 0.0102 & 0.0234 & $0.0522 *$ & 0.0062 & 0.0008 & 0.0059 & 0.0103 \\
\hline PZ11C & 0.3810 & 0.2206 & 0.1694 & 0.0576 & & 0.0259 & $0.0770 *$ & 0.0401 & 0.0260 & $0.0429 *$ & $0.0534^{*}$ \\
\hline RC10A & 0.1365 & 0.4011 & 0.3541 & 0.3287 & 0.4695 & 0.3464 & & 0.0457 & $0.0544^{*}$ & $0.0582 *$ & $0.0763^{*}$ \\
\hline RC11A & 0.2989 & 0.2938 & 0.2065 & 0.1187 & 0.2487 & 0.2071 & 0.2295 & & -0.0035 & 0.0259 & 0.0179 \\
\hline RC11B & 0.2696 & 0.2414 & 0.1631 & 0.0766 & 0.1448 & 0.1700 & 0.3007 & 0.0684 & & -0.0011 & 0.0163 \\
\hline RC11C & 0.3100 & 0.2402 & 0.1157 & 0.0994 & 0.2331 & 0.2323 & 0.3723 & 0.2081 & 0.0589 & & 0.0169 \\
\hline
\end{tabular}


Figure S1. Quantification of DNA in Alexandrium minutum cultures in comparison with nuclei isolated from human blood cells (HBC, 6.4 Mbp), after staining with propidium iodide in PBS buffer. HBC and A. minutum are discriminated on the forward scatter (X-axis, logarithmic scale), a proxy of size, versus red fluorescence (Y-axis, linear scale) dot plot (A). Quantification of DNA (X-axis, linear scale) by fluorescence in two monoclonal strains (B) and (C).

Figure S1:
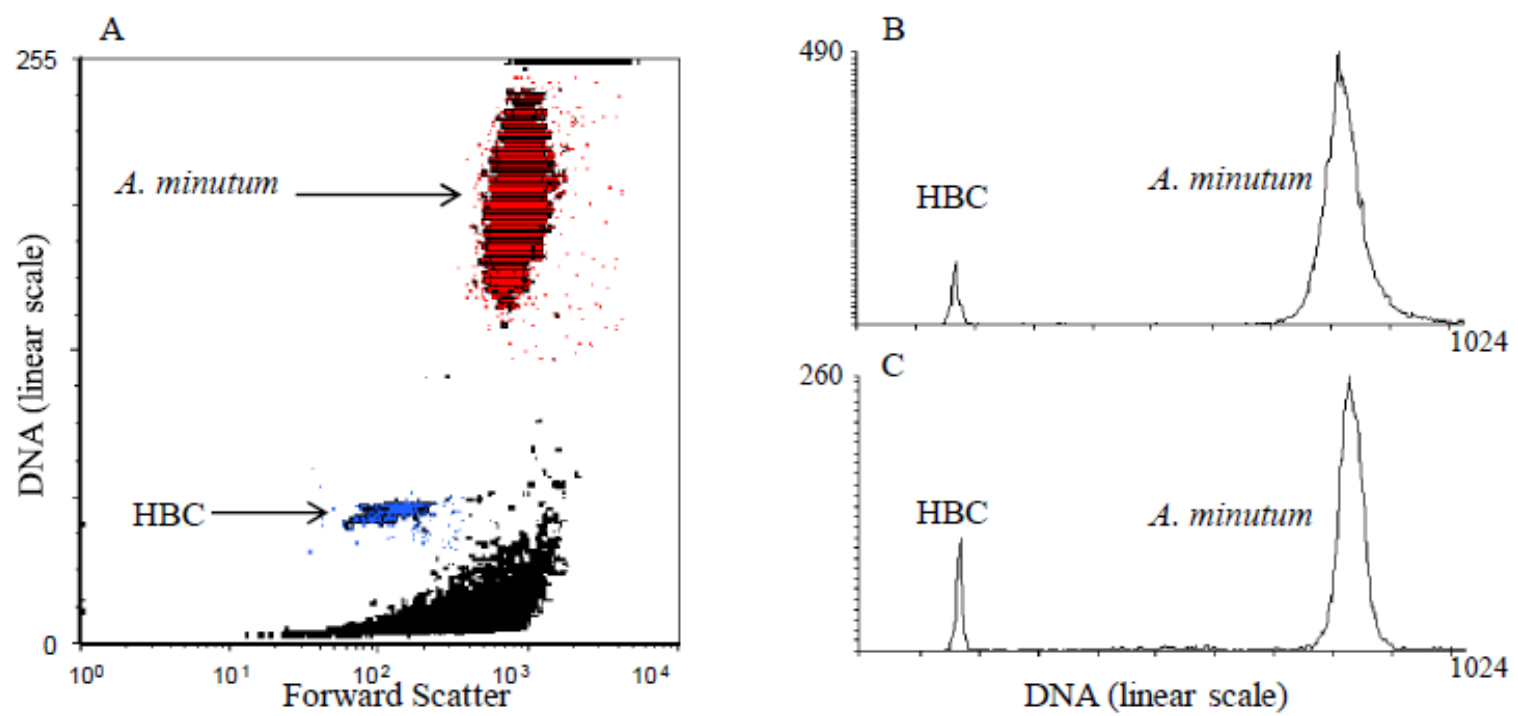

Figure S2. Resolving power of the microsatellite marker set to discriminate the maximum clonal diversity available in the data set.

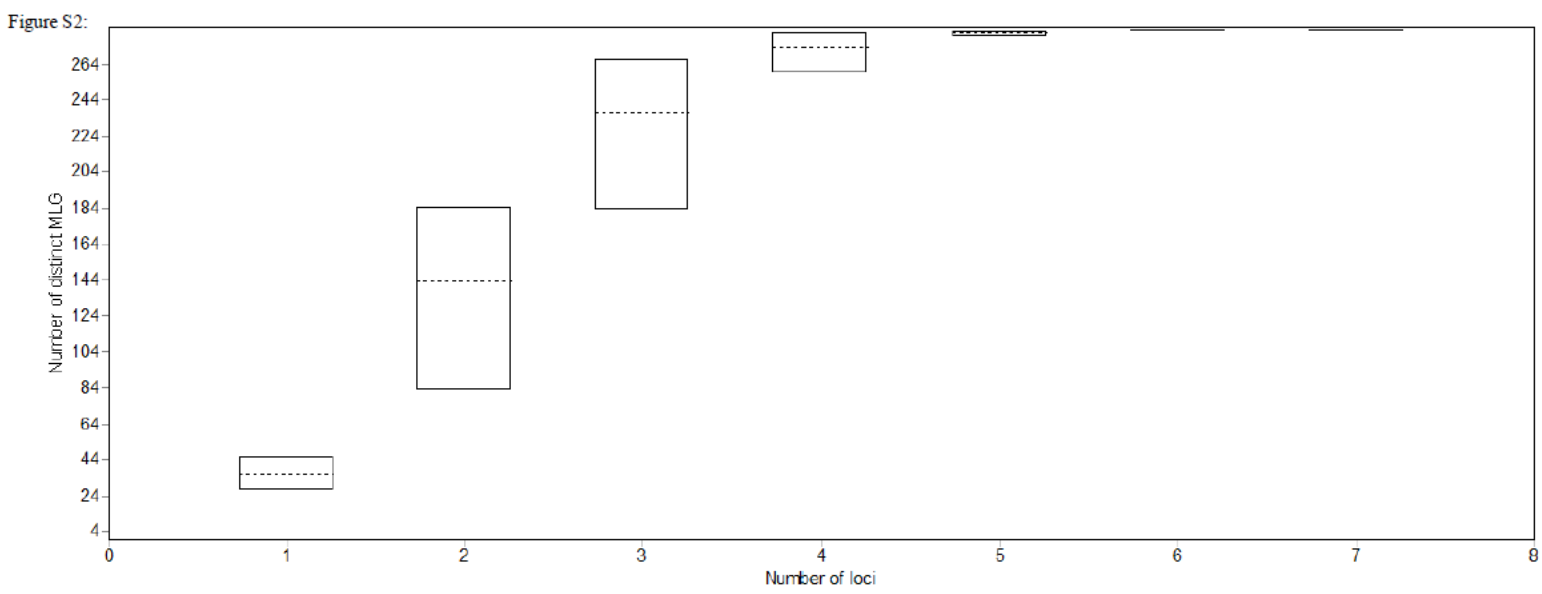

